\title{
الخصائص الموسيقية لأغاني العهل في أربيل
}

\author{
اعداد \\ م.م عمار حليم حامد \\ جمهورية العراق \\ وزارة التربية \\ المديرية العامة لتربية محافظة كركوك \\ المتوسطة الغربية للبنين
}

مجلة بحوث التربية النوعية ـ جامعة المنصورة

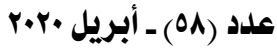




\title{
الخصائص الموسيقية لأغاني العهل في أربيل
}

\author{
إعداد

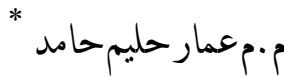

טגil|

تتكون الرسالة الموسومة ( الخصائص الموسيقية لأغاني العمل ِِِ أربيل ) من فصلين

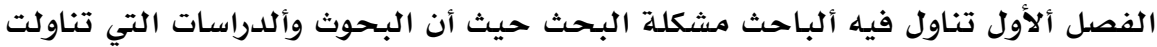

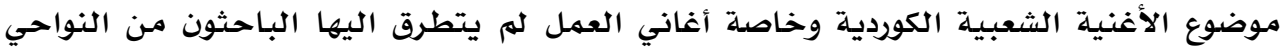

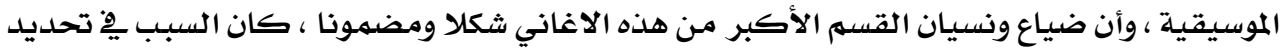

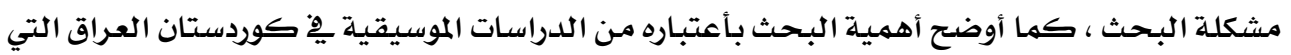

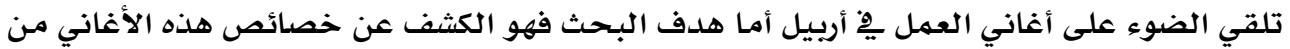

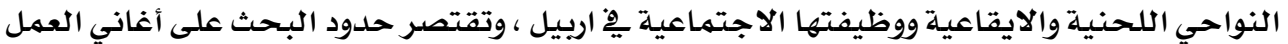

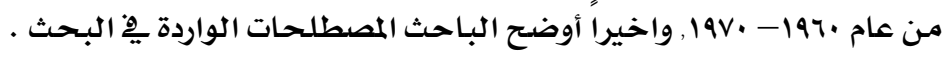
الفصل الثاني يتكون من مبحثين: المبحث الأول يتكون من نبذة تآريخية عن تاريخ مدينة

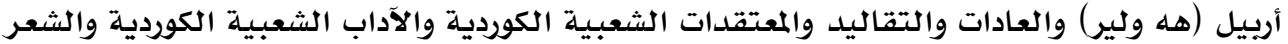

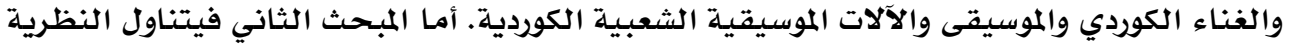

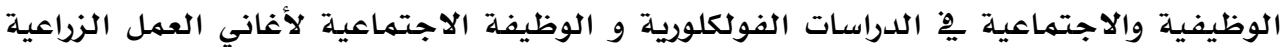

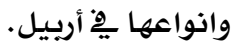

ومن ثم تليها عينة لأغنية العمل الزراعية ثم ملخص باللغة الانكليزية

\section{الفصـل الأول}

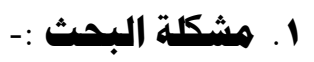

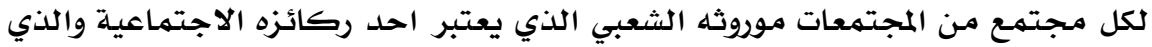

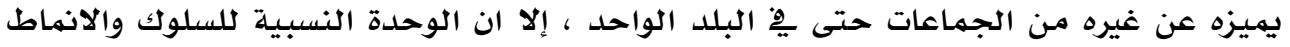

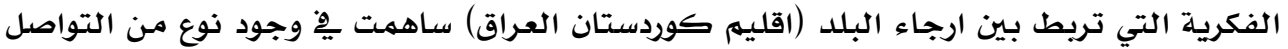

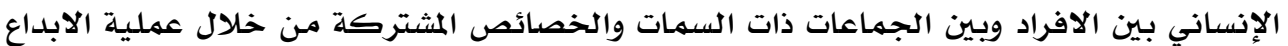

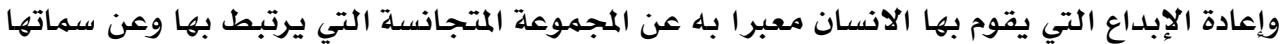




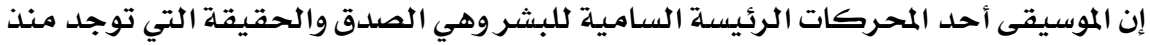

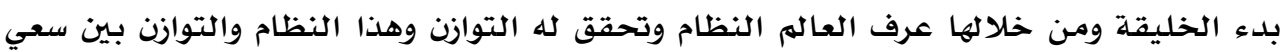

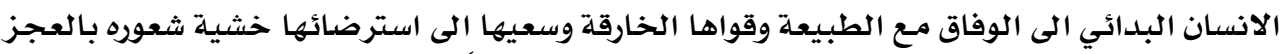

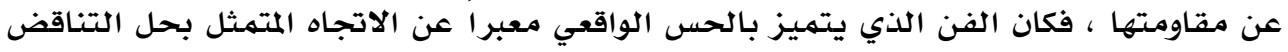

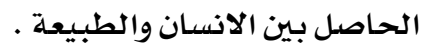

وإن الموسيقى والغناء كجزء من الثقافة وعنصران من عناصره الروحية للمجتمـع وهما

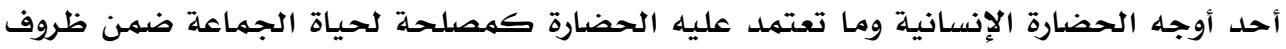

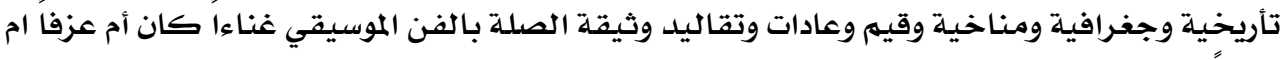

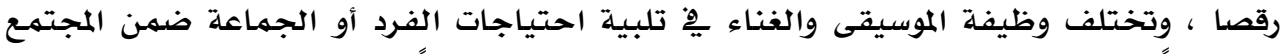

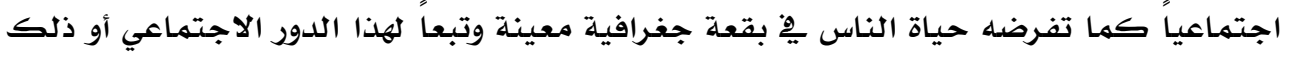

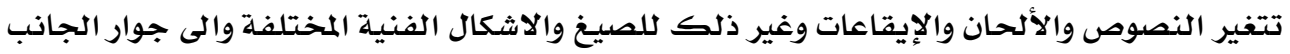

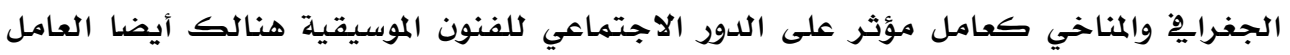

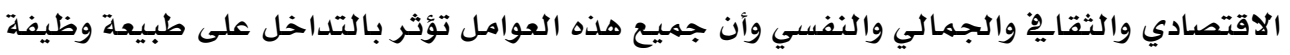

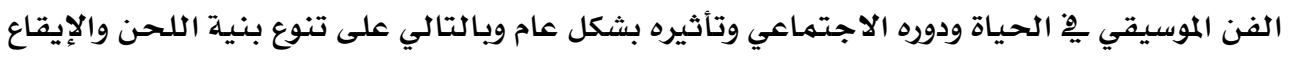

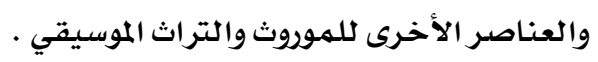

وتعتبر الأغنية الفولكلورية الكوردية من أغنى ميادين الفولكلور الكوردي ، من حيث كثرة

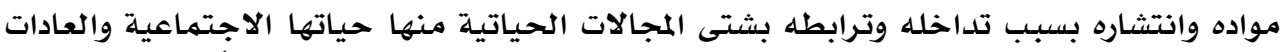

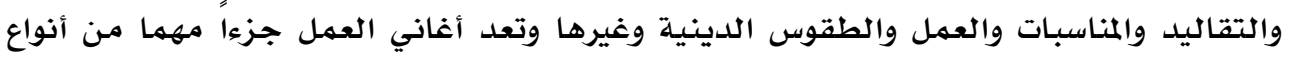

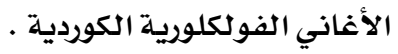

تناولت بعض البحوث والدراسات موضوع الأغنية الشعبية وخاصدة أغاني العمل ِِّ مجالات

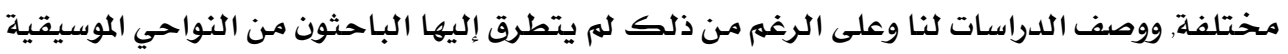

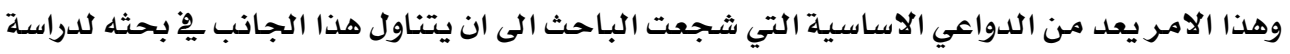

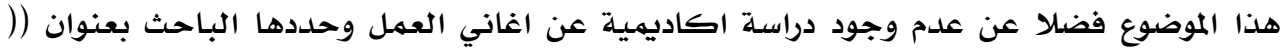

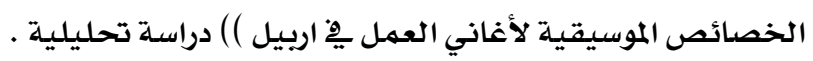

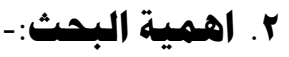

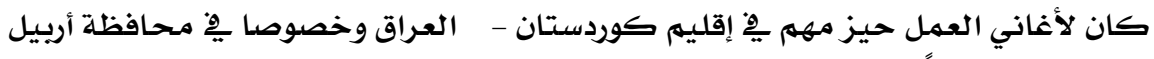

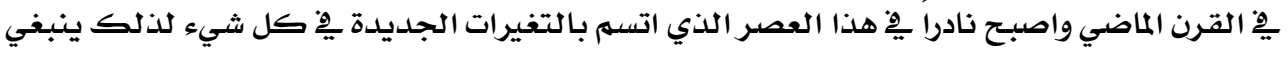

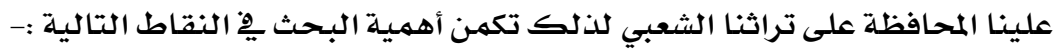

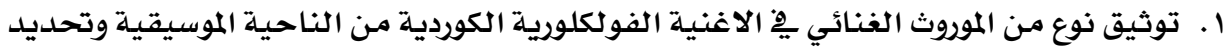

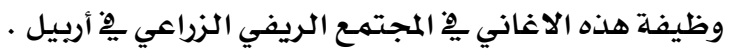

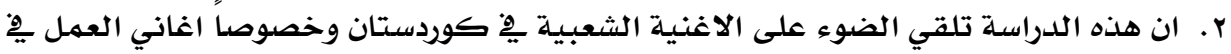

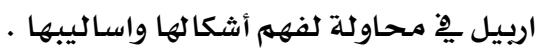




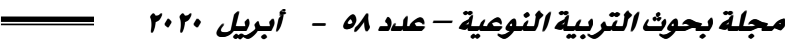

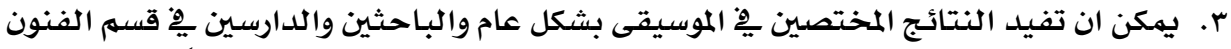

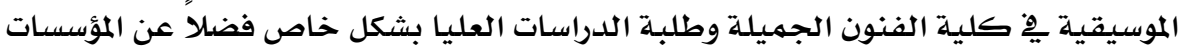

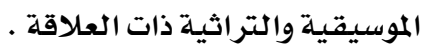

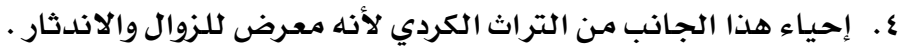

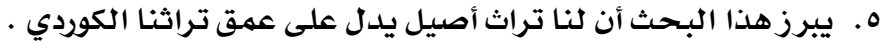

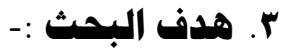

الكشف على أهم وأبرز الخصائص الإيقاعية واللحنية لبعض أغاني العمل ِِّ محافظة

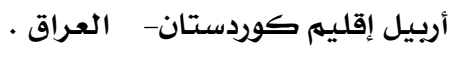

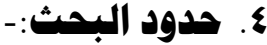

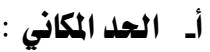

انحصرت هذه الدراسة على محافظة أربيل إقليم كوردستان -العراق ،حيث تم اختيارها

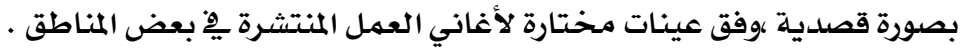

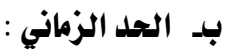

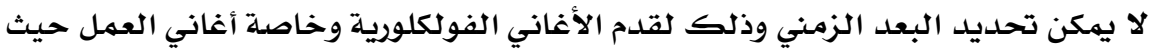

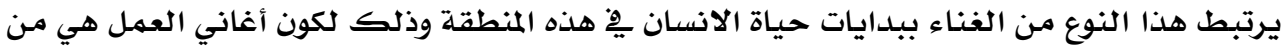

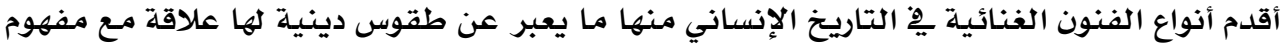

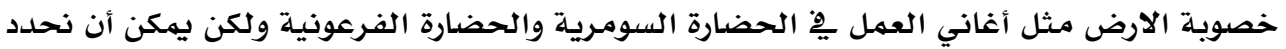

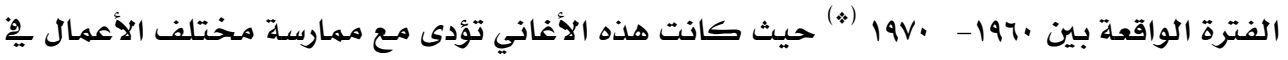

\section{0. تمديد المطاتصات:-}

سيتم تحديد المصطلحات التي وردت فِّ عنوان البحث كالاتي:

1. Properties الخصائص

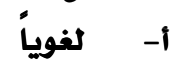

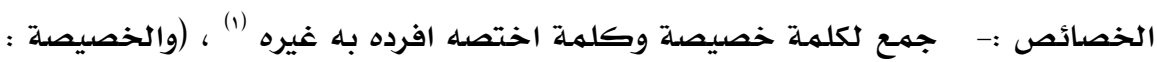

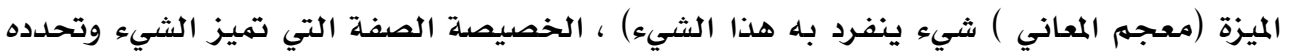

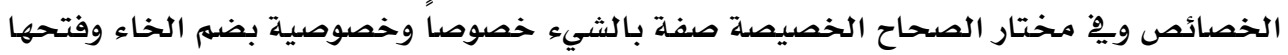

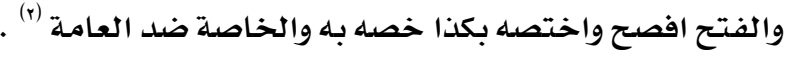

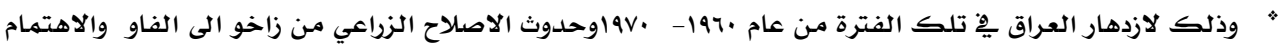
بالفنون كافة ومنها الفنون الشعبية

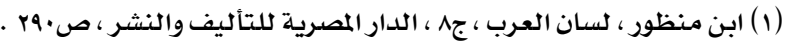

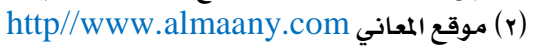


صفة لا تنفك عن الشيء وتتميز عن غيره ، ومن مجموع الخواص يتكون الكيف (1).

هي مركب مواهب فطرية طبيعية تضمن امكانية تربية الذوق الموسيقى عند الانسان،

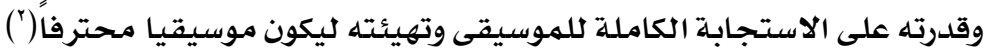

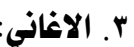

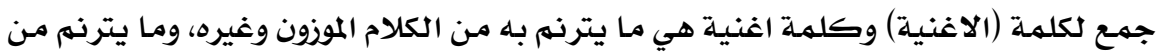

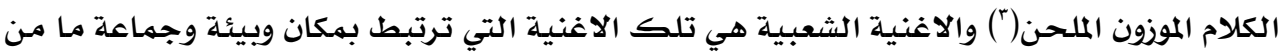

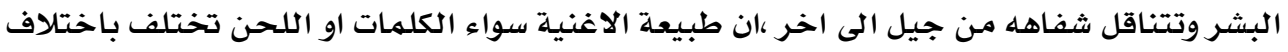

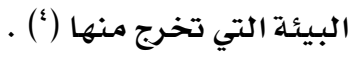

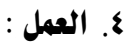

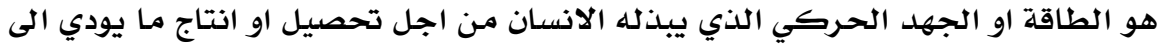

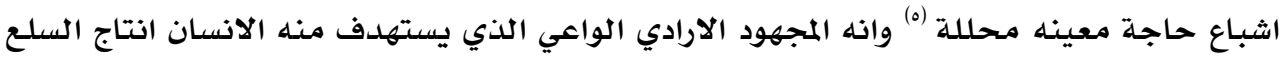

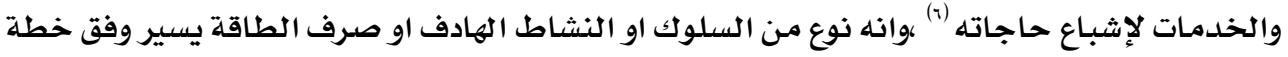

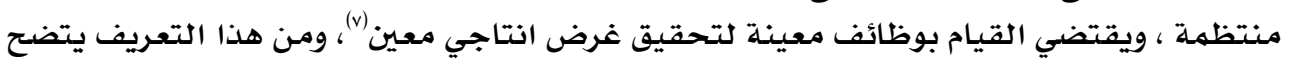

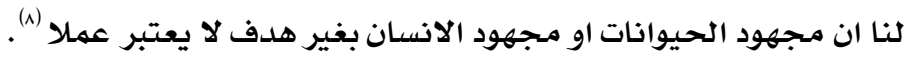

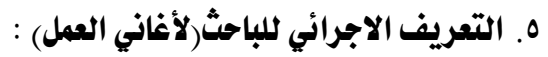

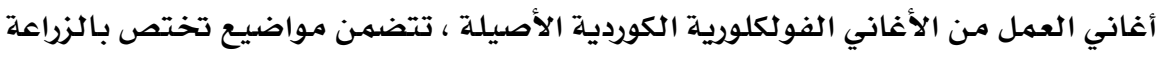

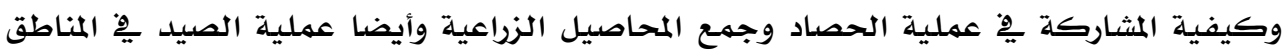

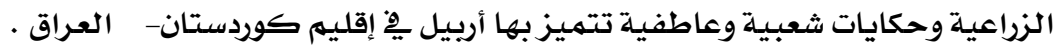

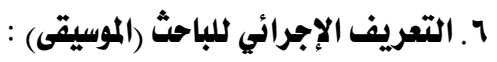

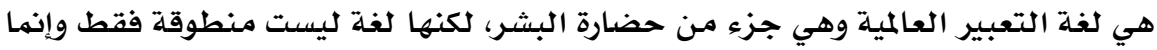

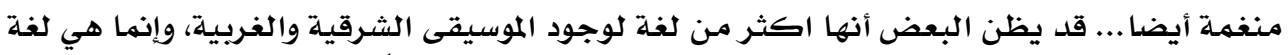
واحدة ويأتي الاختلاف فقط من اختلاف الشعوب واختلاف الآلات أيضاً.

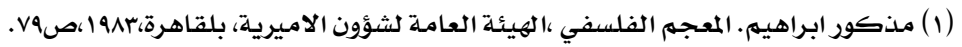

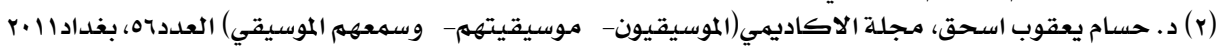

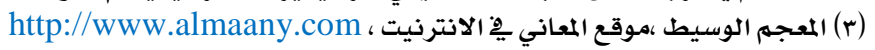

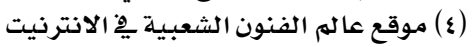
http://www.kenanaonline.com/users/ahmedsalahkhab/posts/97490

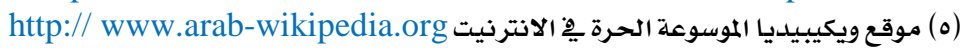

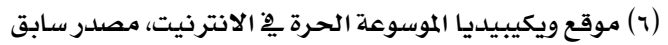

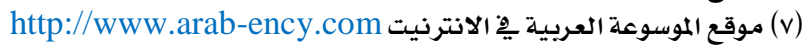

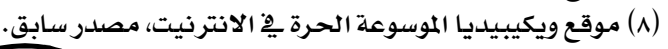


V التصريف الإجرائي للباحث( أربيل ) : البيل

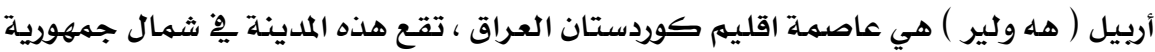

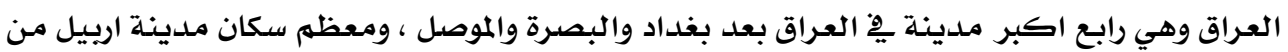

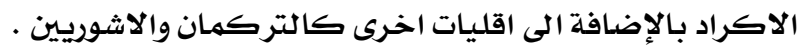
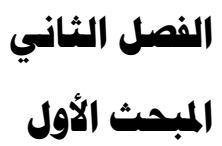

اـ نبذة تاريخية عن تاريخ ملينة اربيل ((هل ولير))

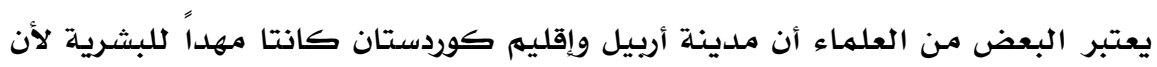

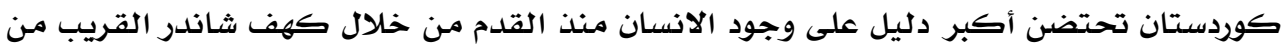

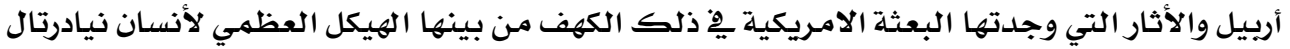

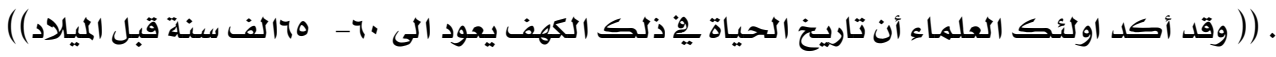

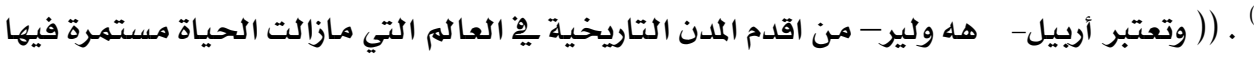

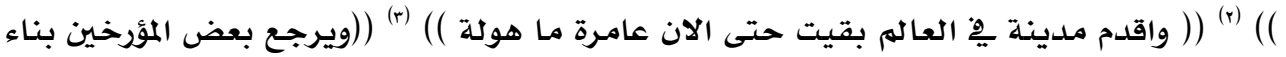

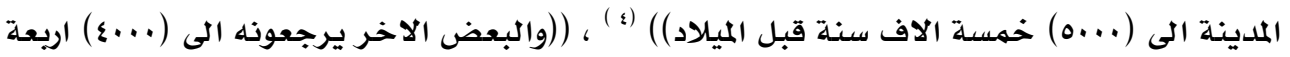

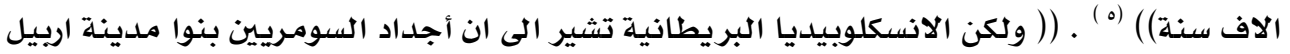

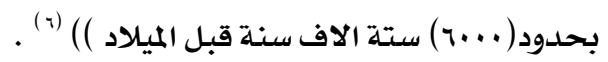

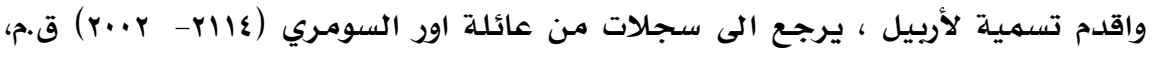

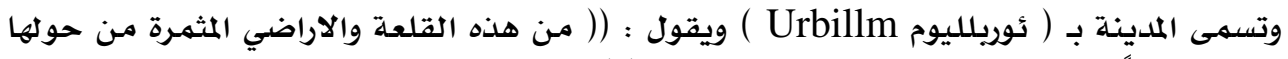

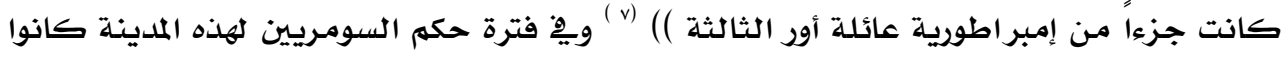

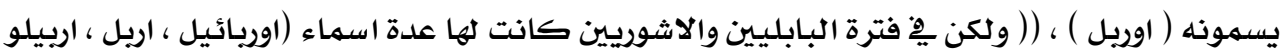

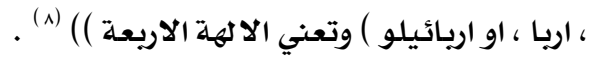
وهنا يقول د. مولود ابراهيم حسين :

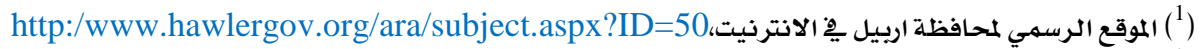

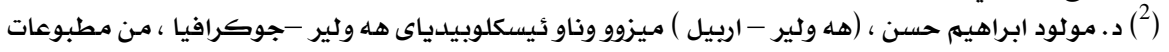

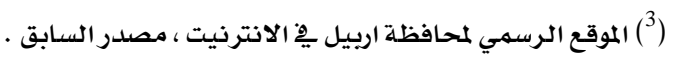

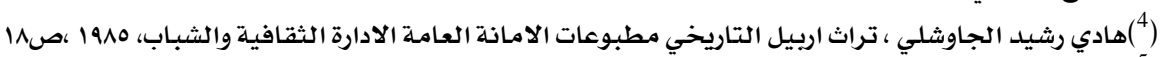

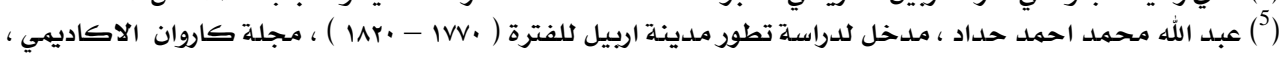

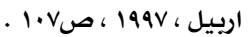

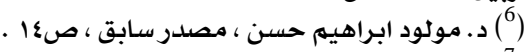

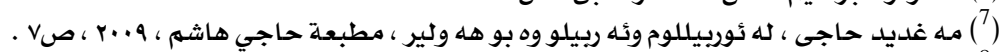

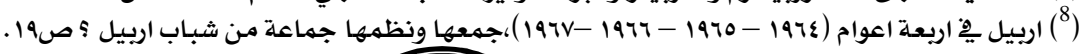




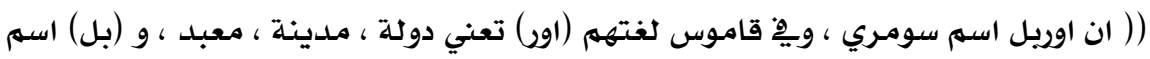

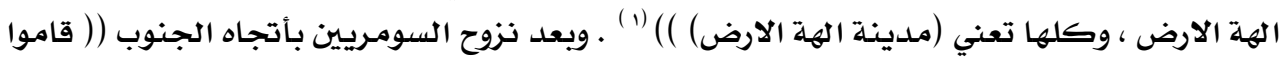

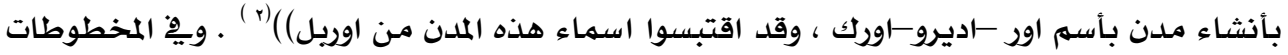

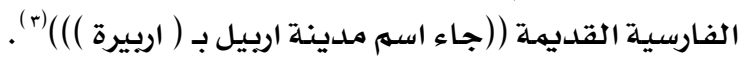

ومن خلال نتائج البحوث التي توصل اليها الباحث ( حوزنيموكرياني ) عند اصل كل كلمة

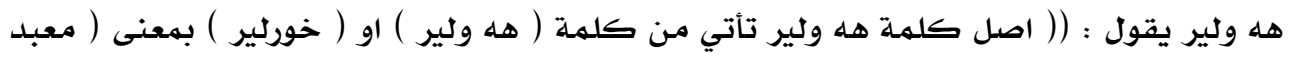

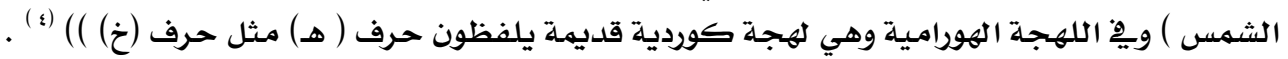

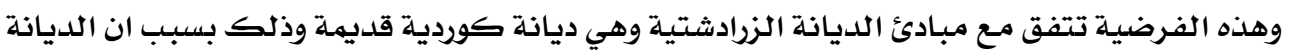

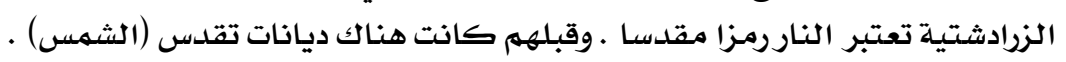

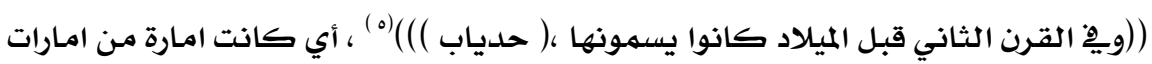

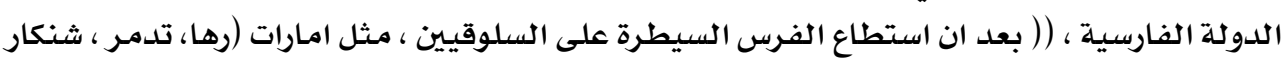

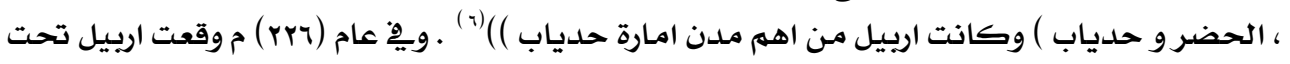

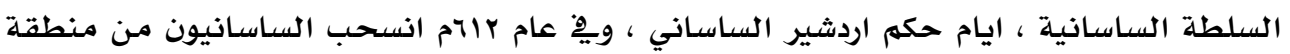

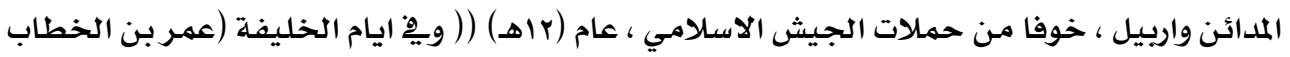

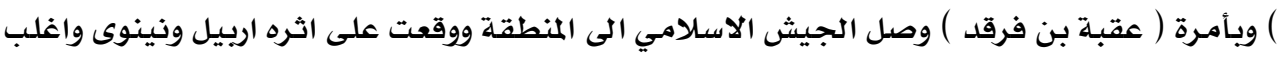

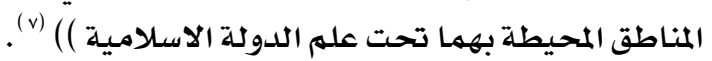

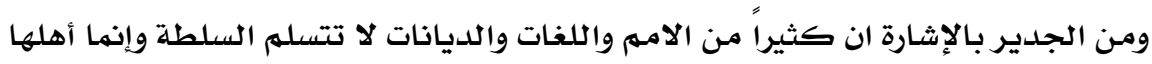

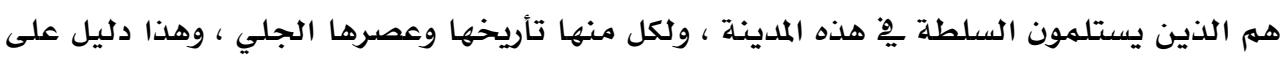

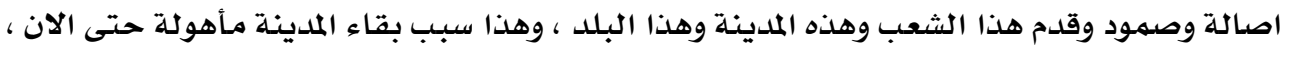

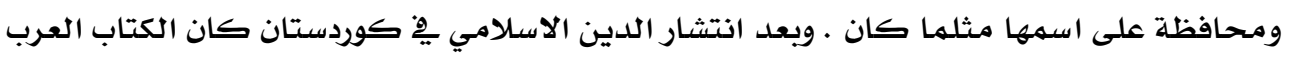

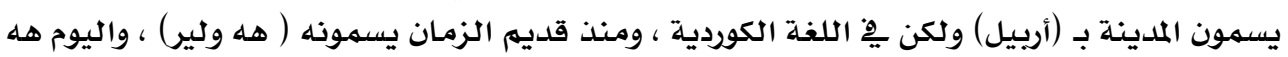

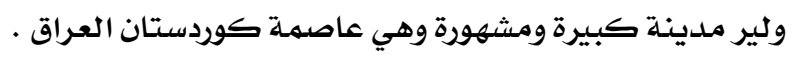

\section{rـ العادات والتقاليد والمعتقدات الشعبية الكوردية}

لجأ الانسان ومنذ القدم الى العديد من العادات والتقاليد وحافظ عليها كالأخلاق

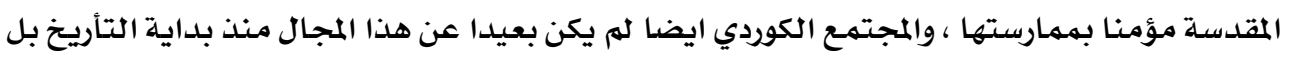

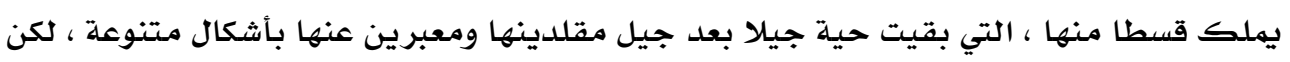

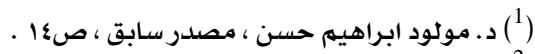

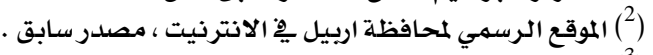

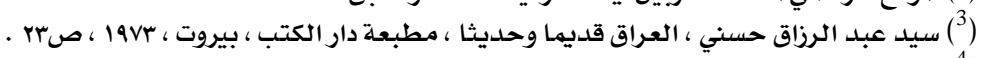

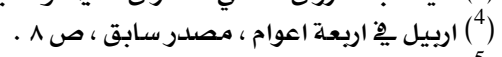

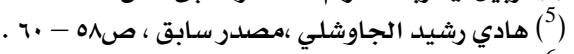

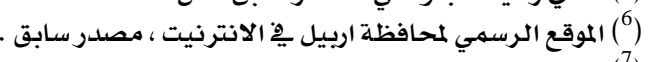


هذه الامور تمارس بقلة وتعرضت للنسيان هذه الايام ، وان كانت متبقية فهي تمثل يِّ إطار فولكلوري

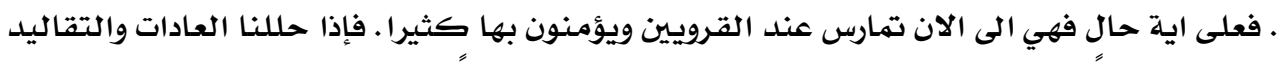

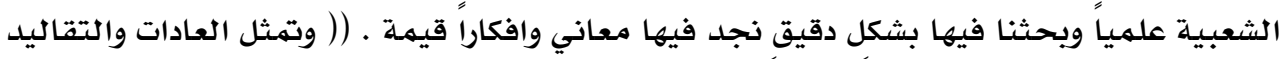

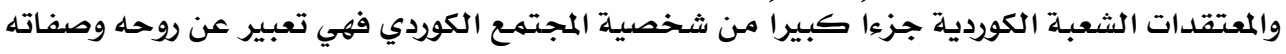

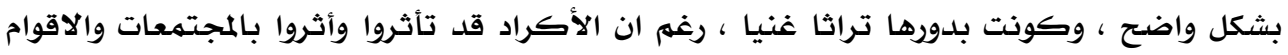

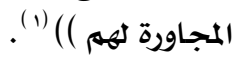

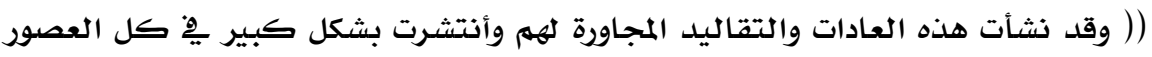

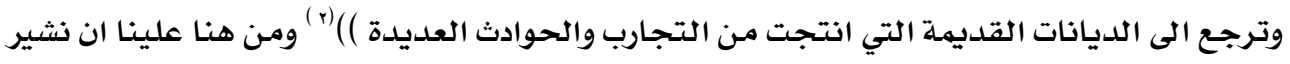

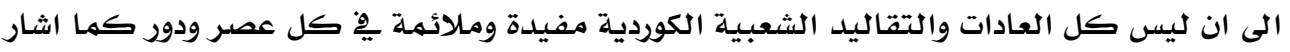

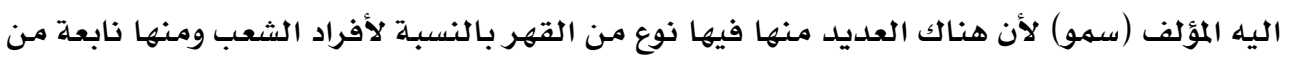

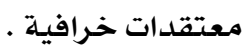

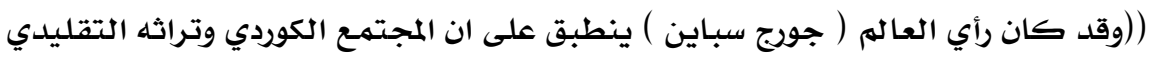

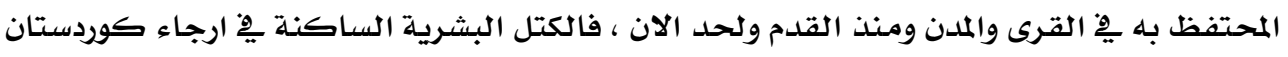

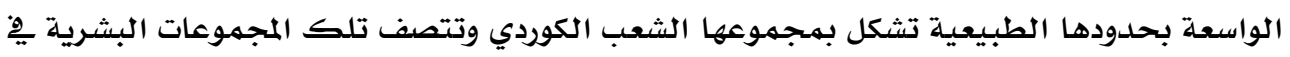
وحداتها الاجتماعية المحلية مهما قرب بعضها او ابتعدات من حيث المسافة او اولئ الدائرة الميكانيكية ذاتها

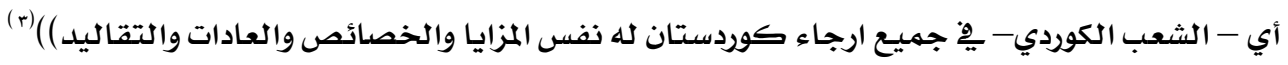

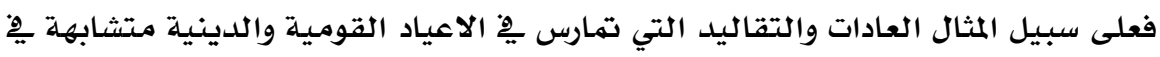

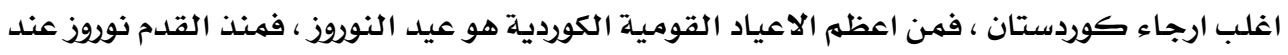

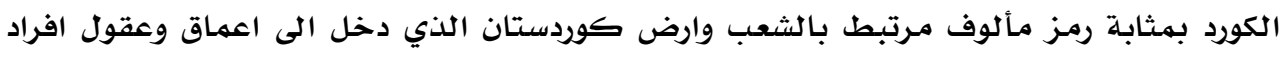

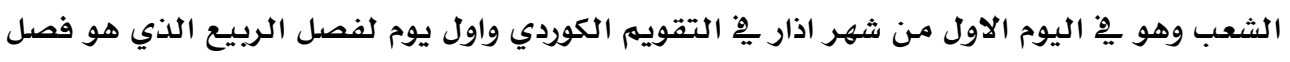

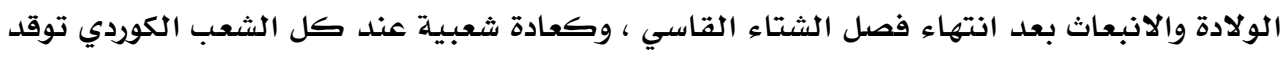

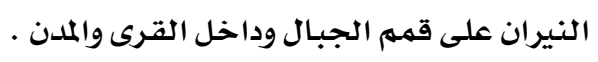

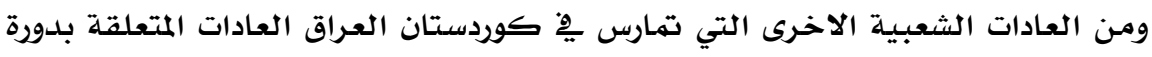

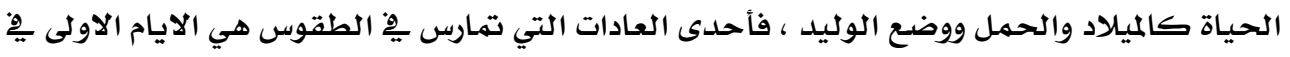

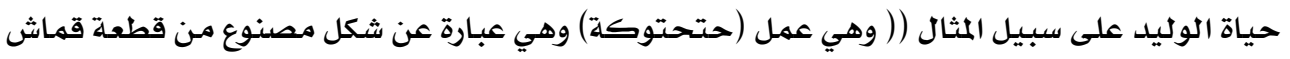

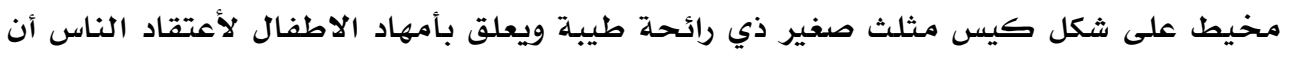

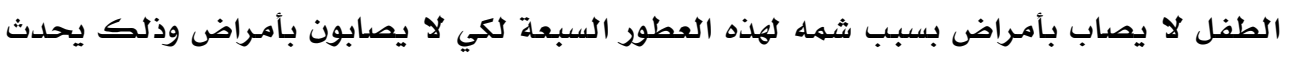

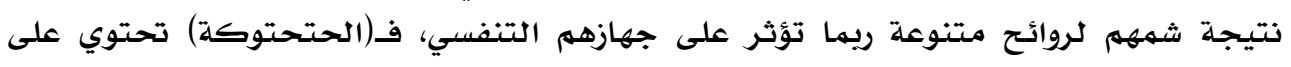

( )

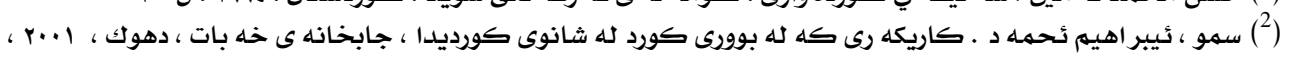

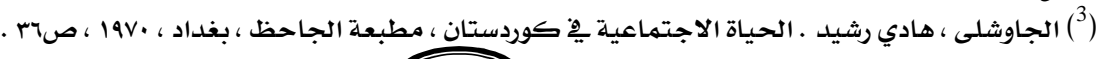


مجموعة روائح من سبعـة ورود تسمى بـ (ميخه لك وكوله باخ وريحان وسميلورازيانه و نعناوورشكه )

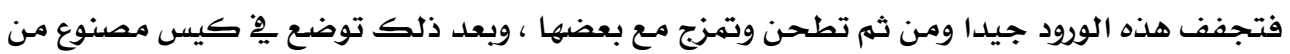

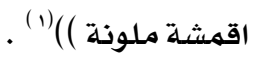

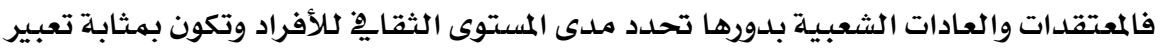

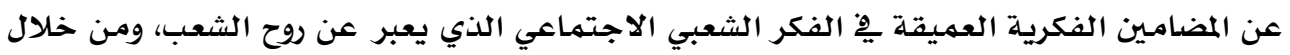

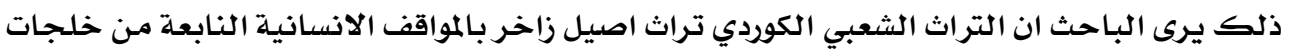
افراده.

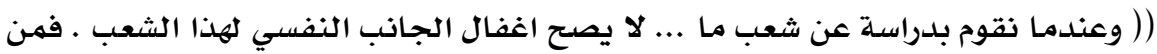

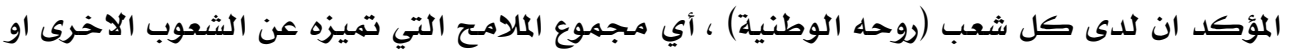

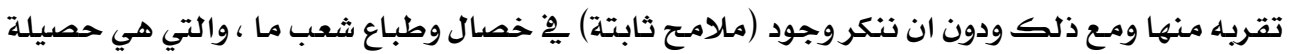

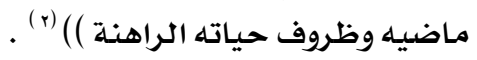

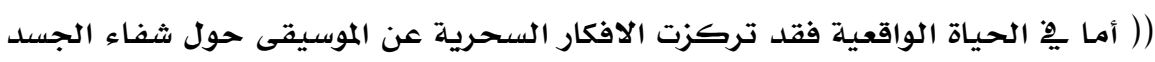

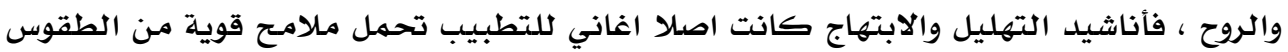

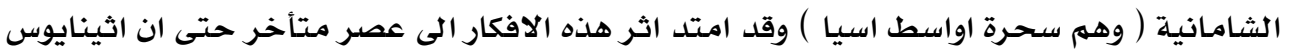

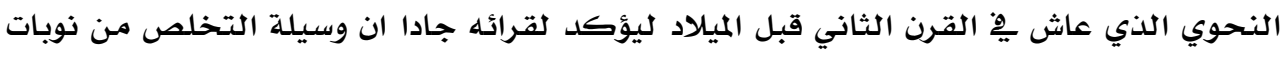

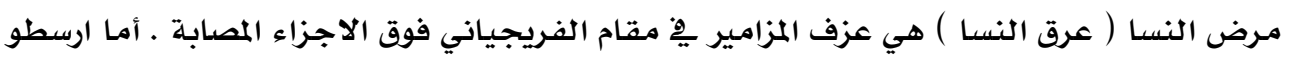

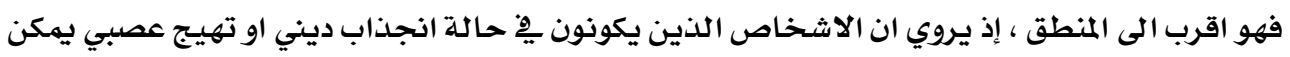

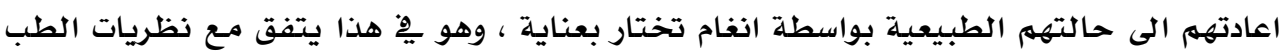

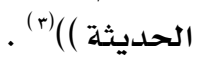

( ( تلك المعتقدات هي ان تفسر لماذا ظهر المؤلف الموسيقي الكريتي ثاليتاس الى جانب

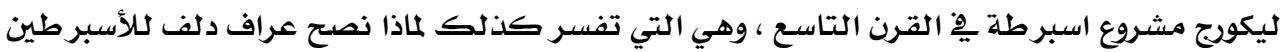

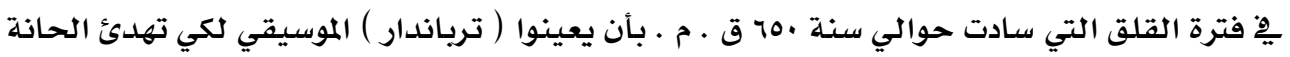

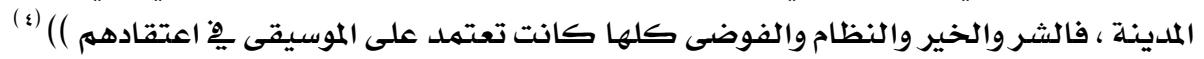
(( وللوشه وظائف جمالية خصوصا بالنسبة للمرأة التي كانت تزين يدها او شفتها

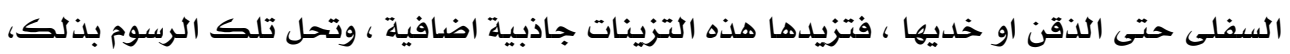

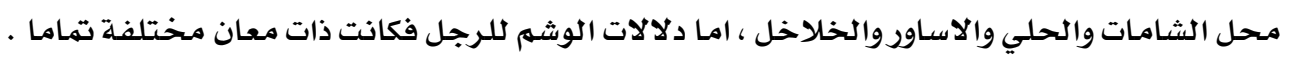

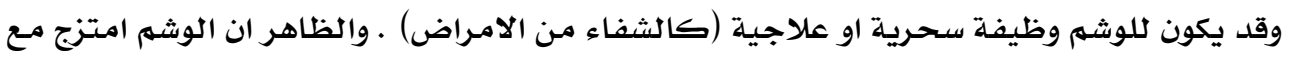

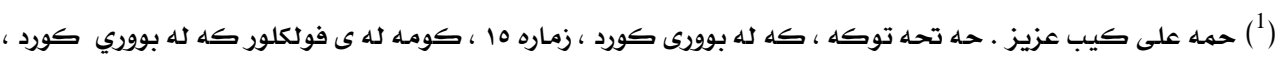

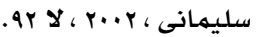

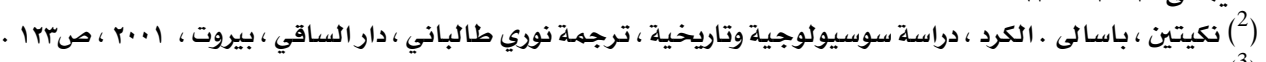

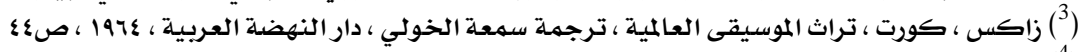

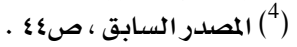




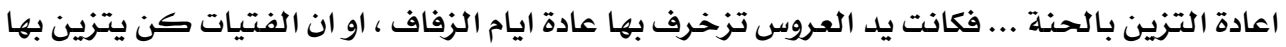

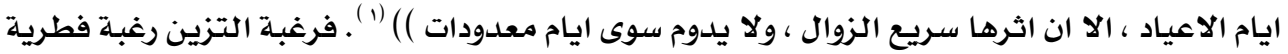

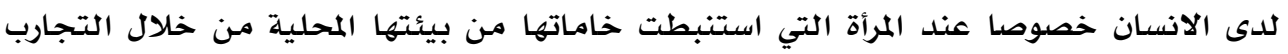
والخبرات المتوارثة المتناقلة . لاندان

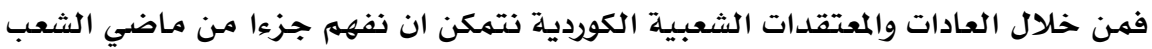

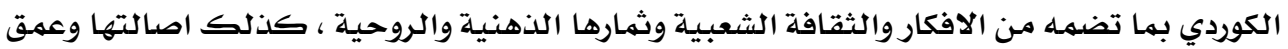

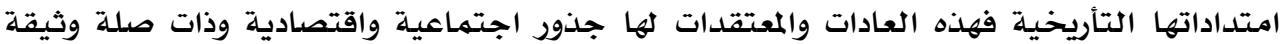

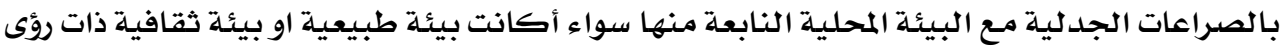
انسانية مختلفة .

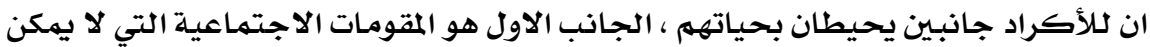

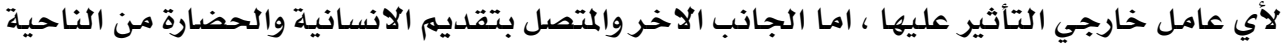

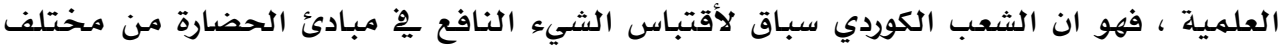

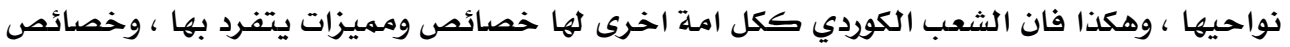

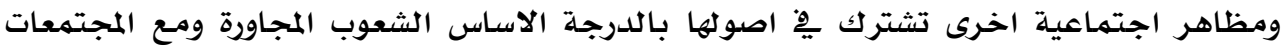

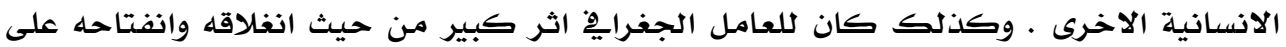

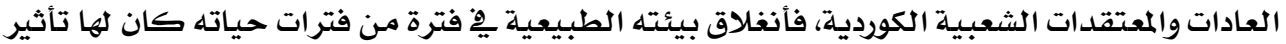
على ثبات افكاره ، والعكس صحيح

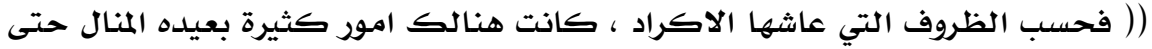
السنوات الاخيرة يِّ الاستخدامات ، فقد كان من النادر ان تتواجد مستشفى او مكان للتداوي

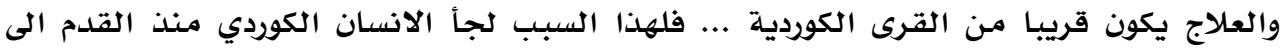

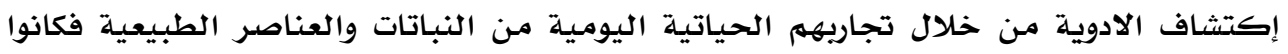

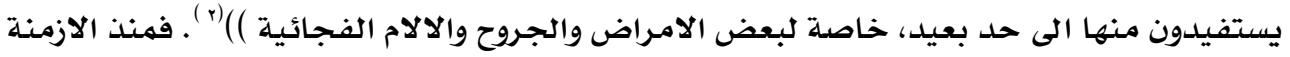

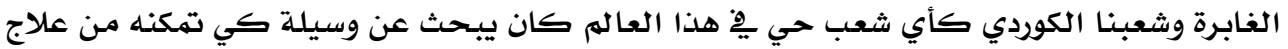

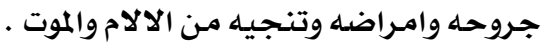
(فبصدد هذا ودون شك تم اكتشاف حشائش ونباتات متنوعة يِّ كوردستان تم

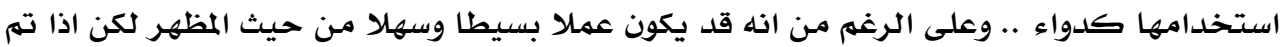

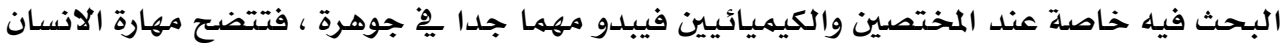

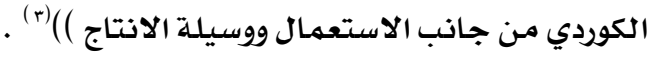

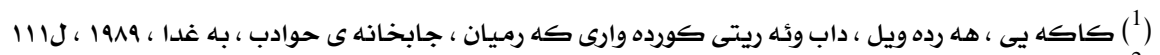

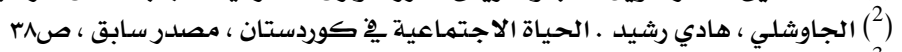


هِّ أي عصر وِِّ أي مرحلة من مراحل خصوصياتها ، (( فالتغير ونشوء المعيشة والحضارة

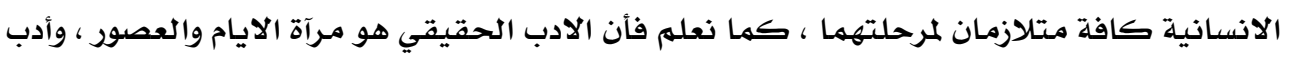

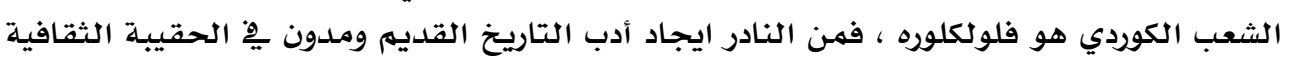

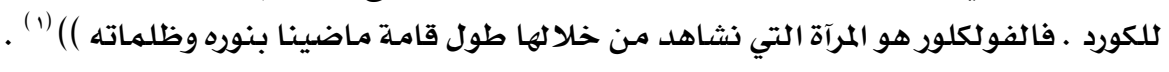
وادب الشعب الكوردي هو تعبير عن انفعال عاطفي وفكري للشعب الكوردي واللغة الكوردية

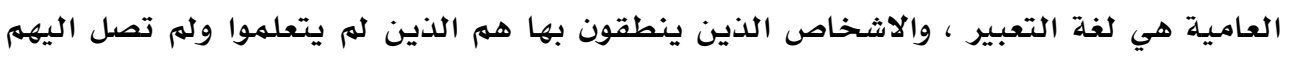

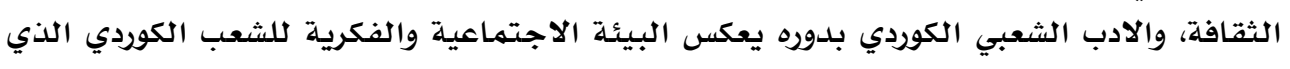

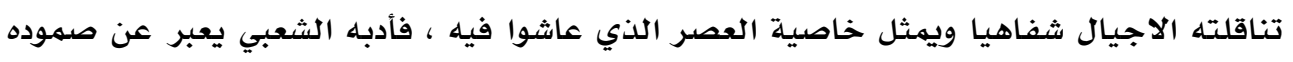

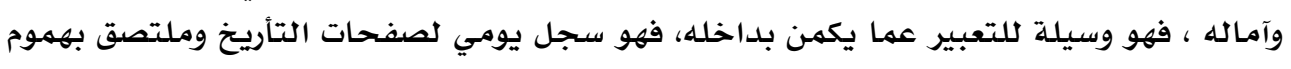

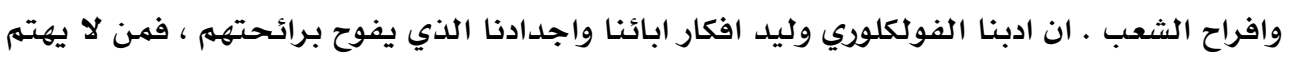

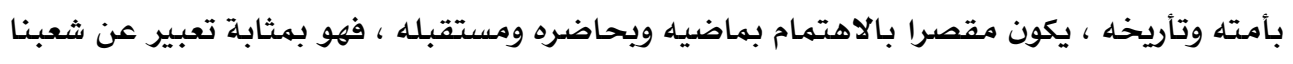

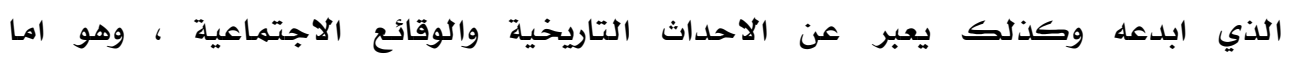

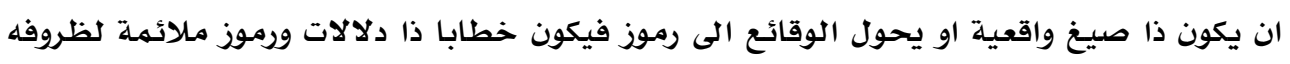

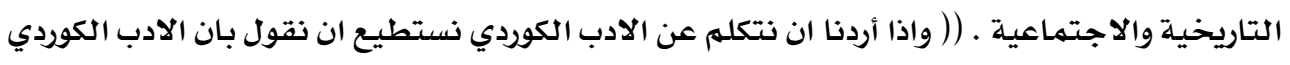

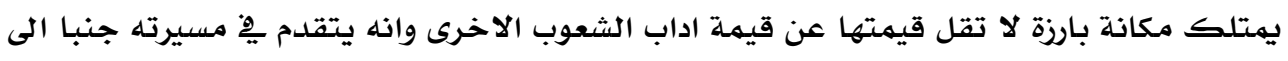

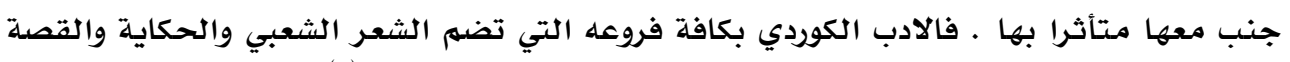

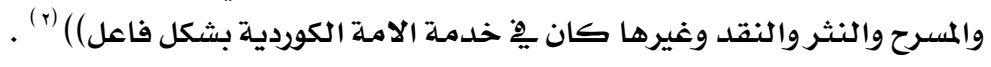

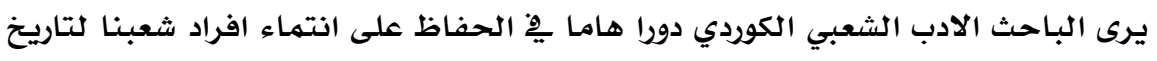

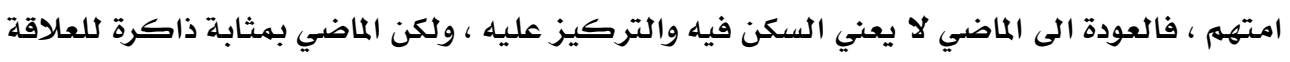

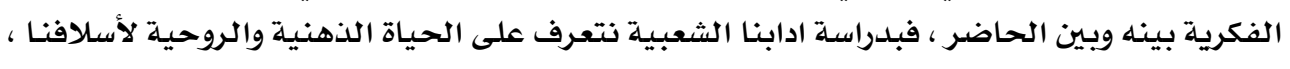

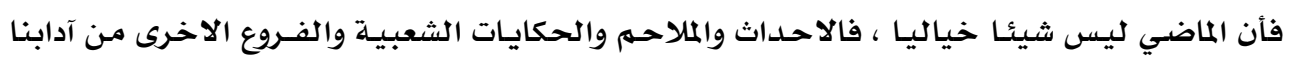

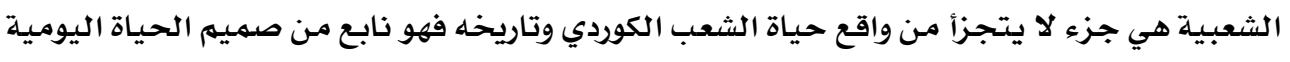

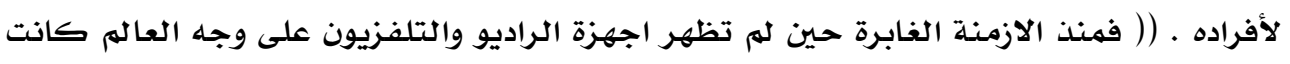

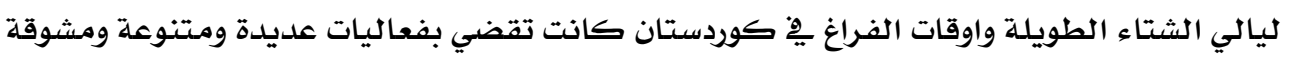

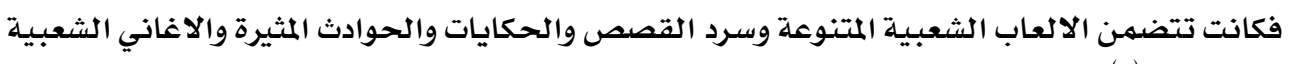

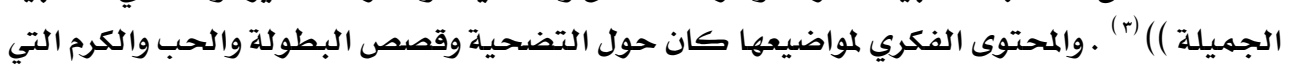

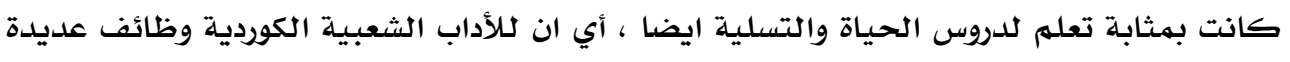

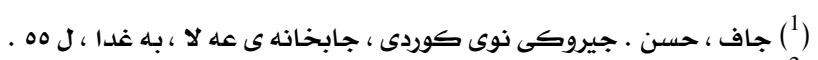

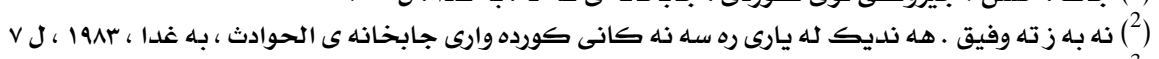

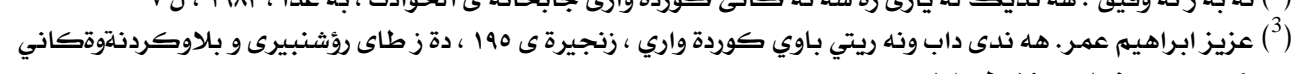


أهمها الوظيفة الثقافية والقومية وهي نابعة عن وجدان شعبنا ، وبدوره يحافظ على التراث الشعبي

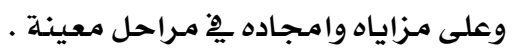

على مدى تاريخ الشعب الكوردي، فأن أي حادث سياسي او تاريخي مهم، او أي حادث

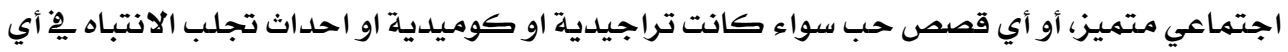

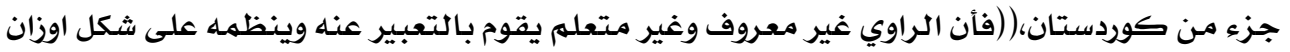

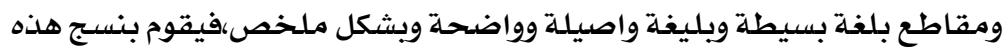

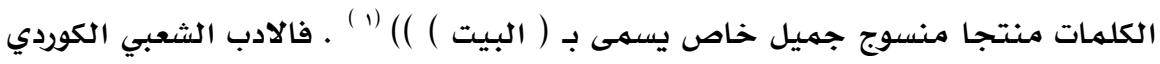

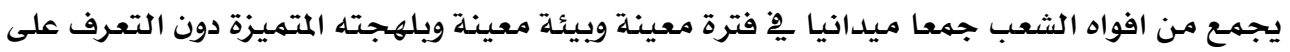

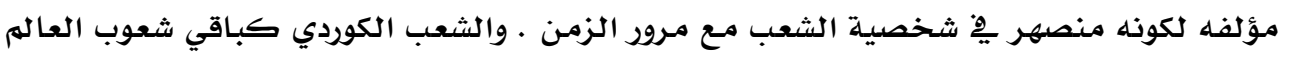

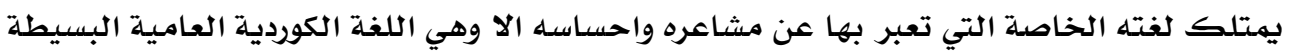

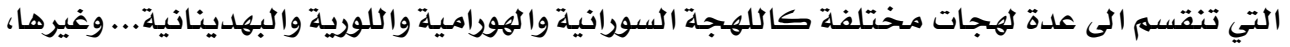

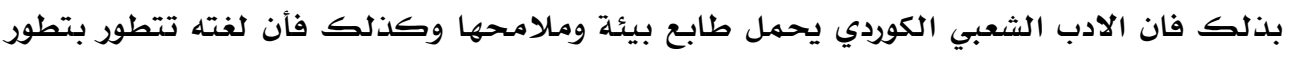

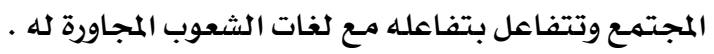

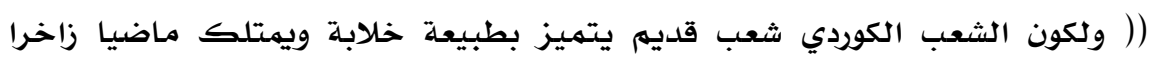

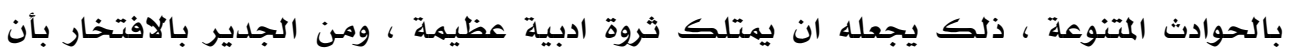

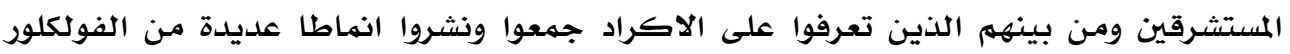

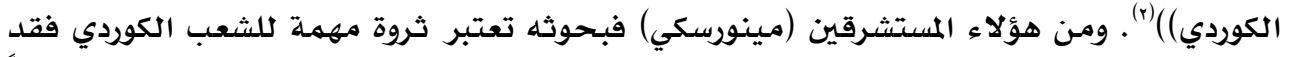

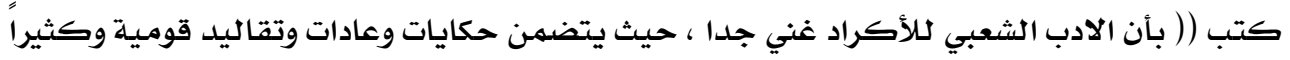

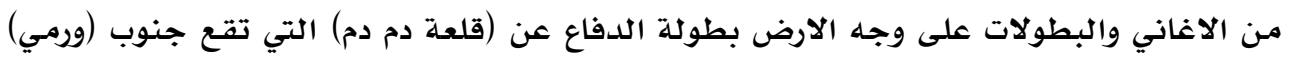

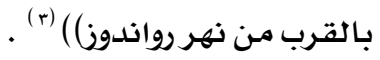

كما كتب مستشرق اخر وهو (فاسيلي نيكيتين) (*) يقول (( بأن الادب الفولكلوري

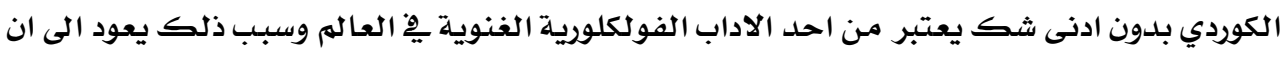

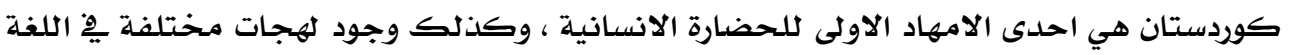

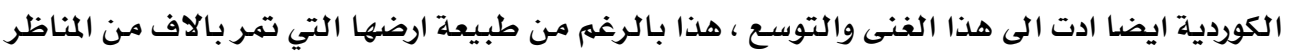

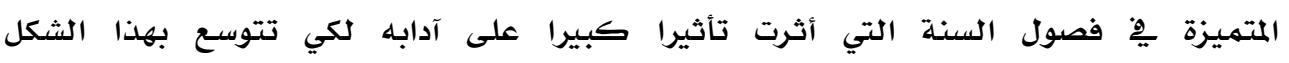

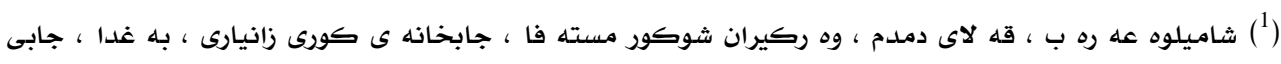

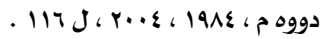

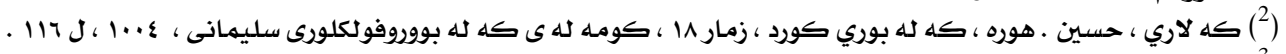

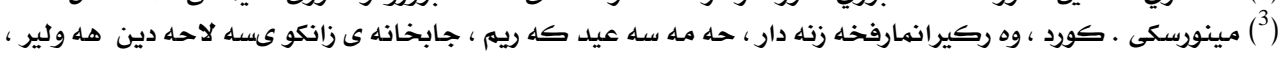
. AV J ا $19 \wedge \mathrm{r}$

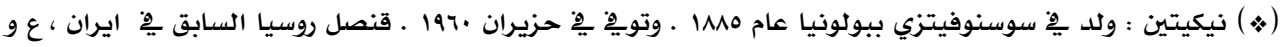

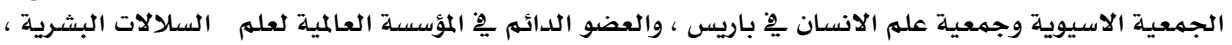

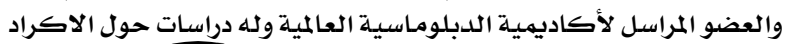


والغنى )(") ) فهي ذات سمة قومية متميزة وفريدة والآداب الشعبية الكوردية تختلط فيها التجارب التهاب

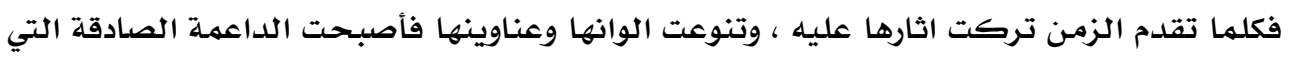

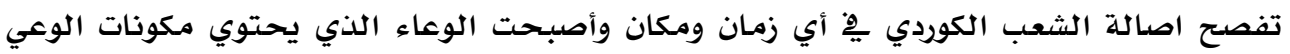

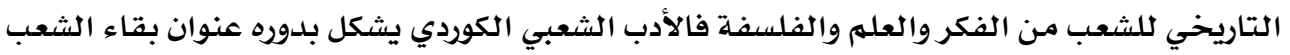

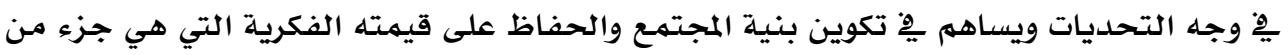

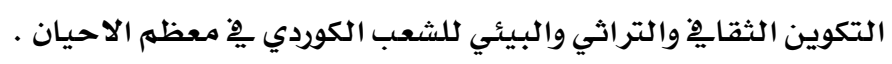

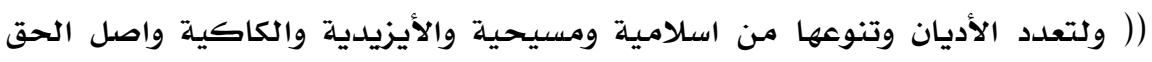

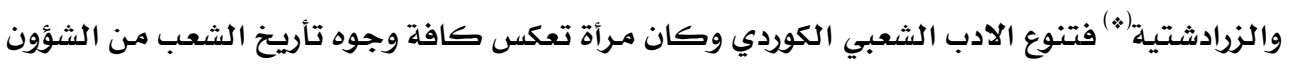

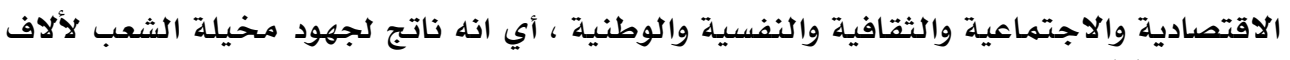

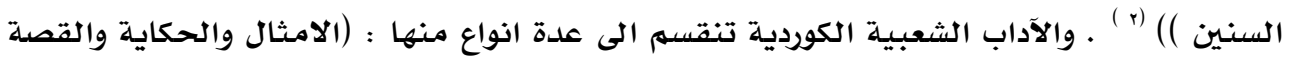

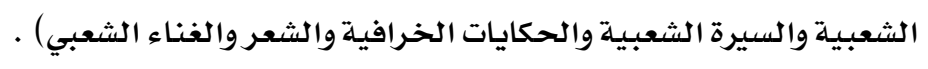

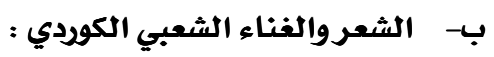

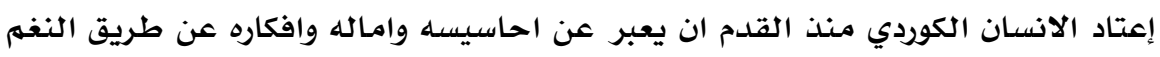

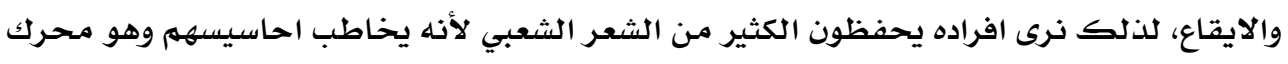

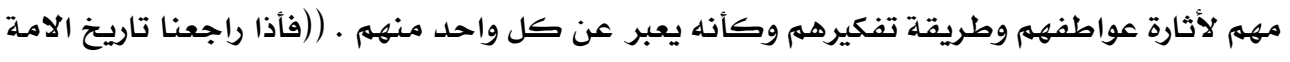

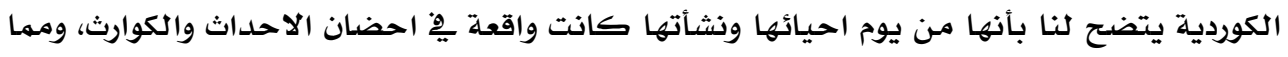

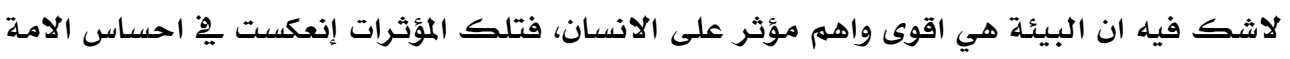

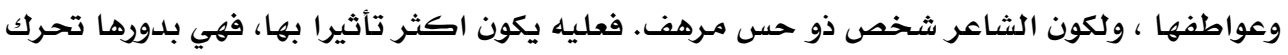

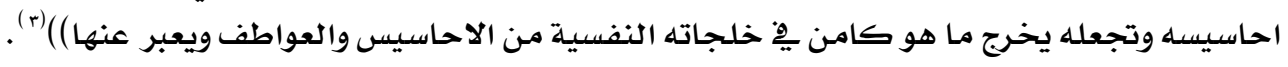

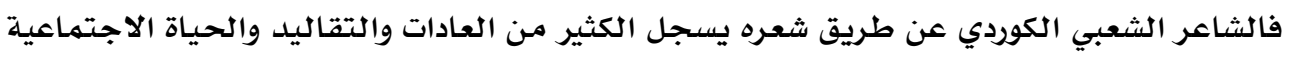

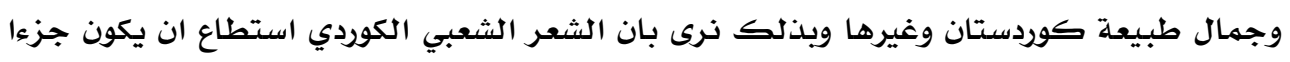

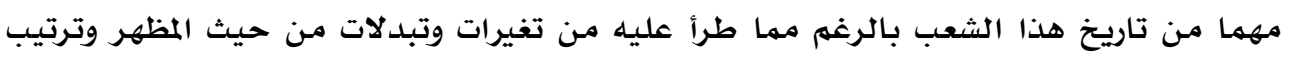

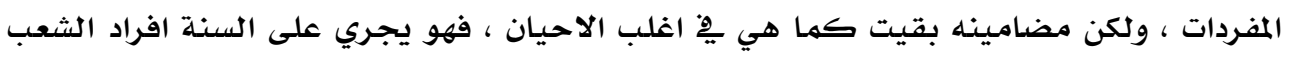

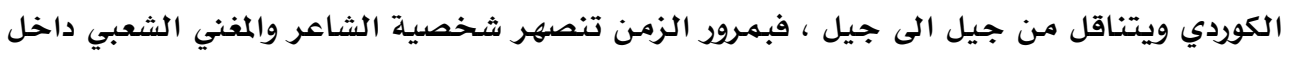

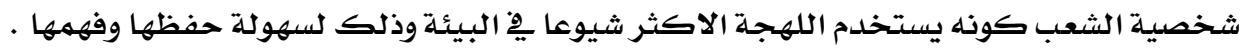

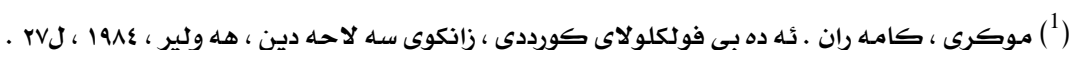

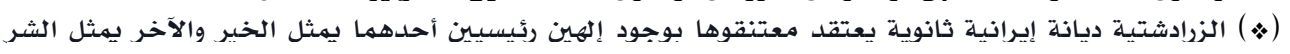

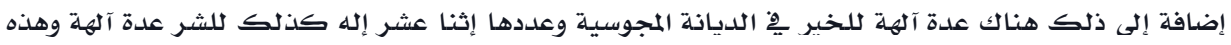

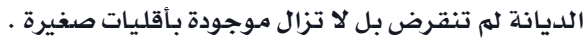

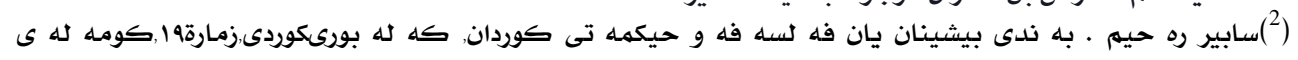

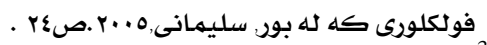

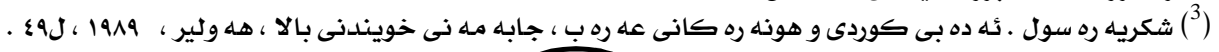




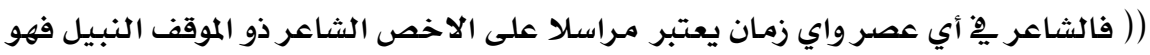

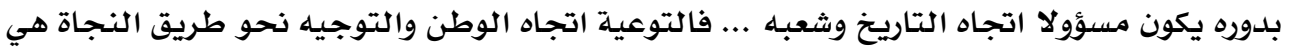

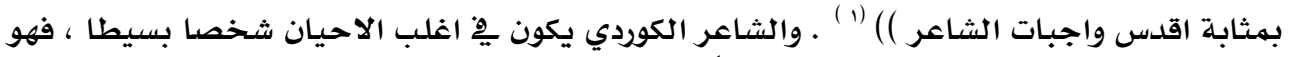

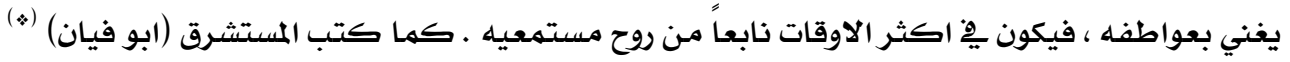

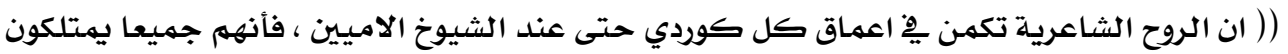

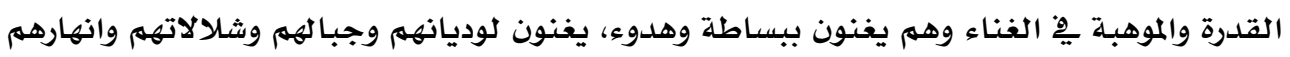

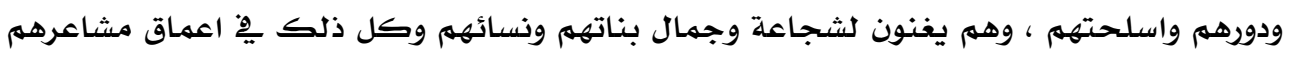

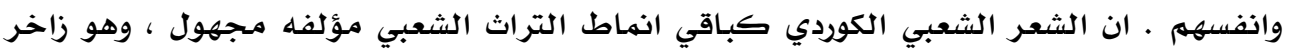

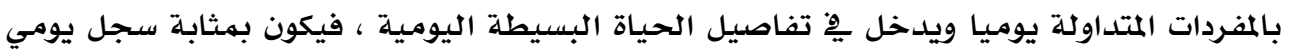

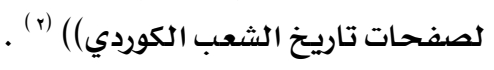

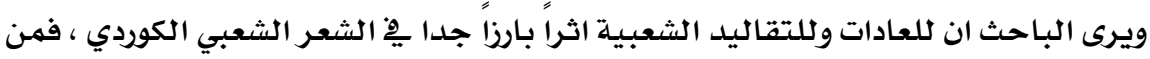

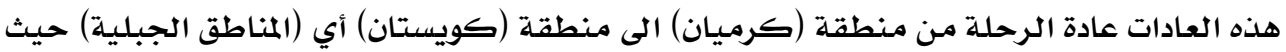

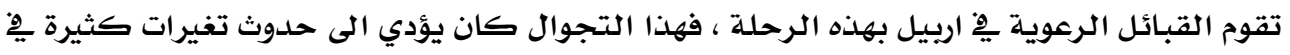

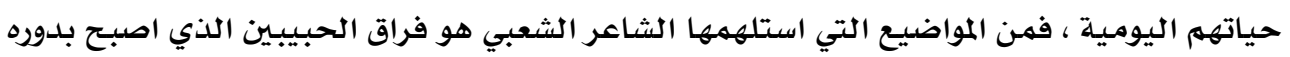

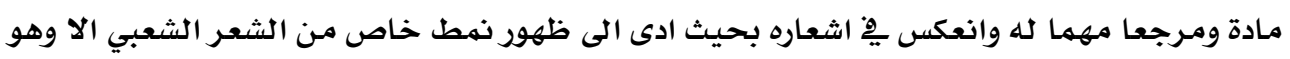

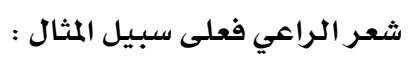

$$
\begin{aligned}
& \text { ( ( شوانى هو شوانى } \\
& \text {..... . . . . . . . } \\
& \text { شوانى ره نجه رو } \\
& \text {... يالِتعاسة حَظِّكَ ... }
\end{aligned}
$$

بستيك مندال بووم ، مـه يلهم دابـه تو

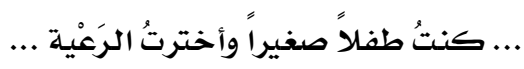

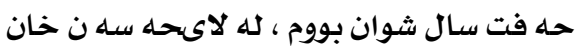

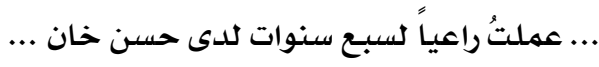

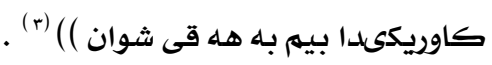

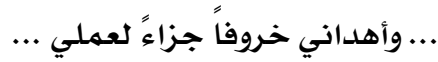

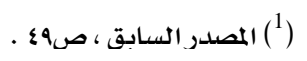

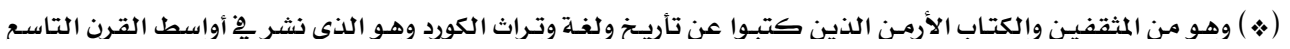

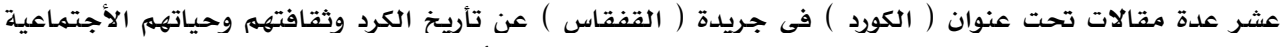

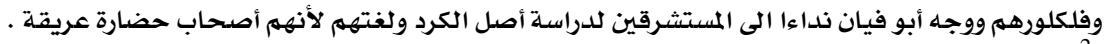

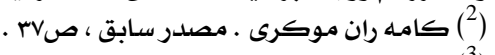

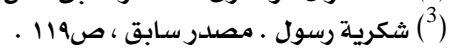


وللشعر الكوردي الوان متعددة دينية وشعبية ووطنية تعبر عن الوعي ازاء قضايا الوطن

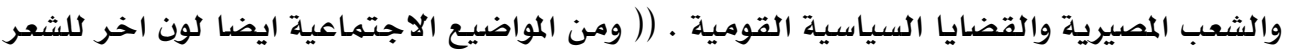

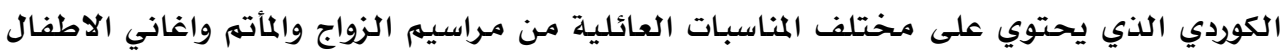

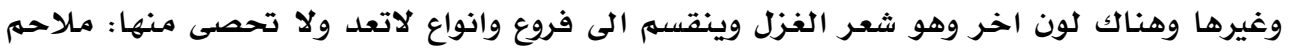

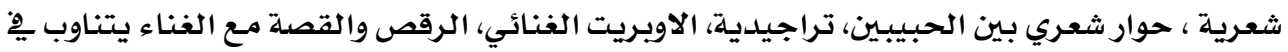

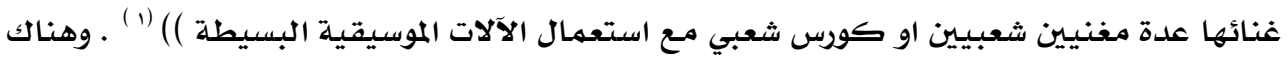

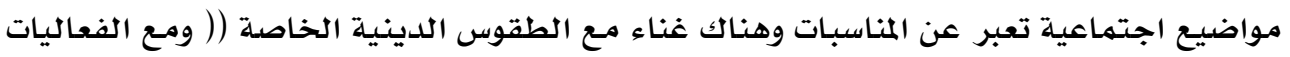

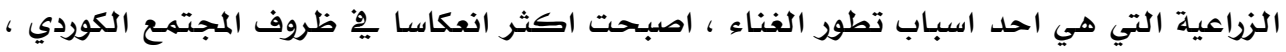

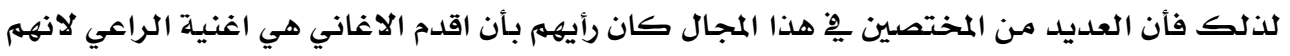

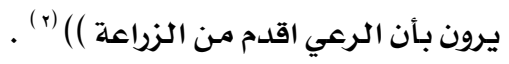
ان المرء يذهل كيف استطاع الاكراد ان يتناقلوا مقطوعاتهم الشعرية بهذه الدقة والجودة. زمـن اغاني العمل هي :

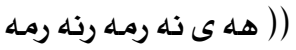

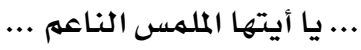

هاوينان جـه نده كاه رمـه

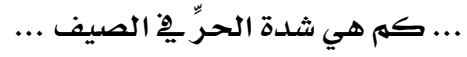

زستانان شهل خته و سـه رمـه

.... والشتاءُ بارد وقارص ...

هاتم نه رمى رامووسهم

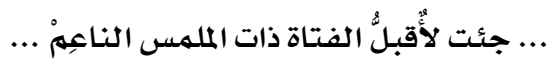

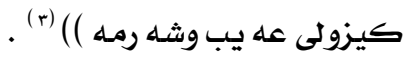

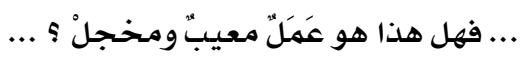

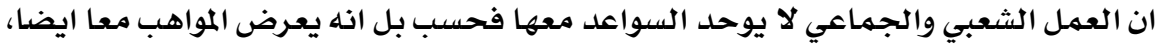

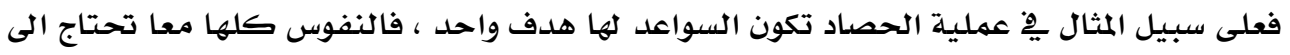

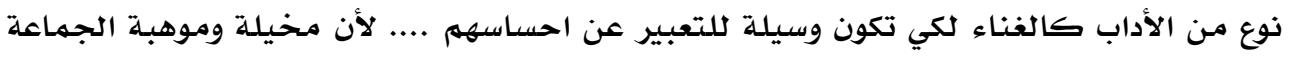

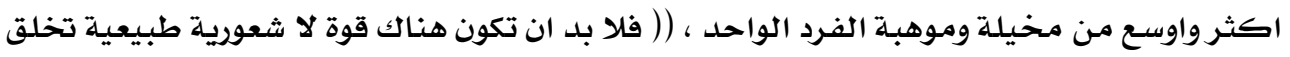

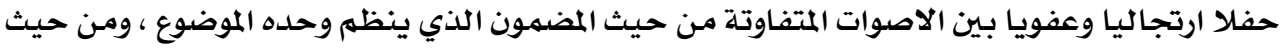

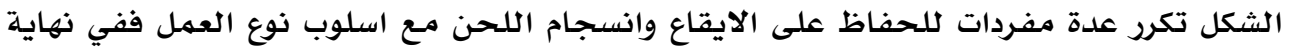

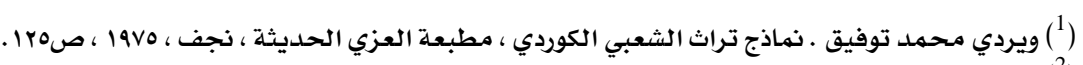

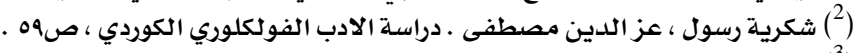

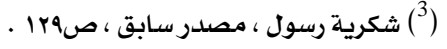




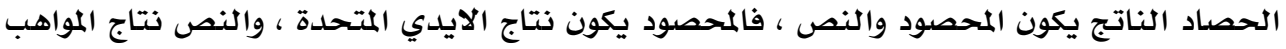

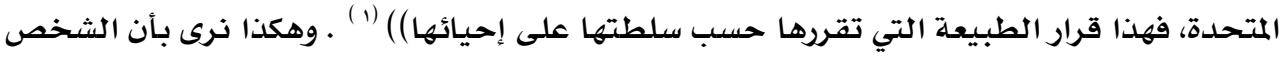

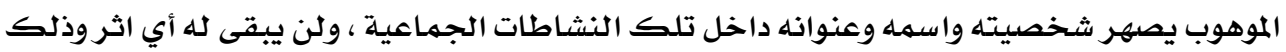

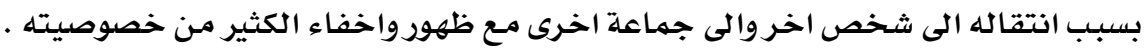

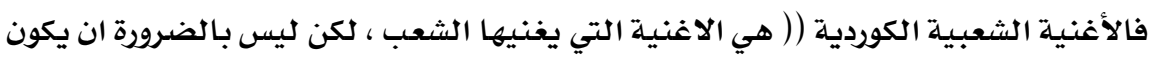

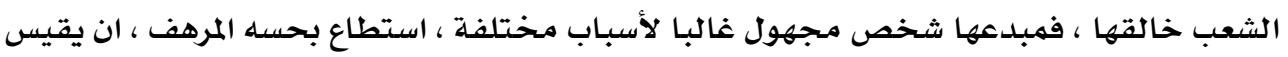

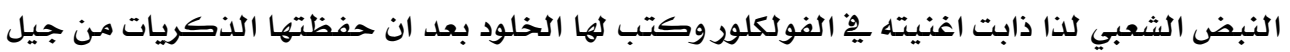

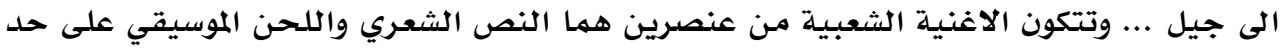

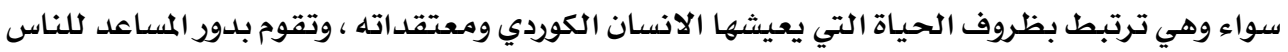

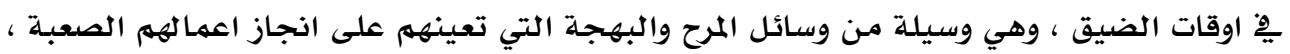

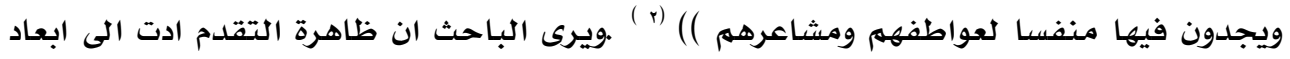

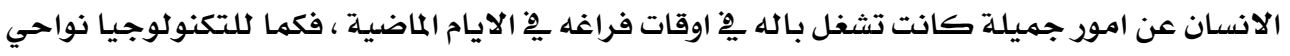

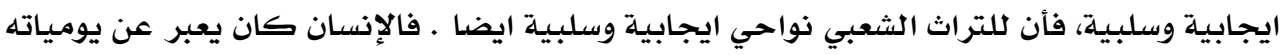

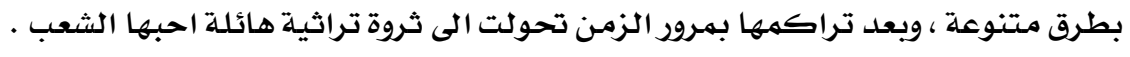

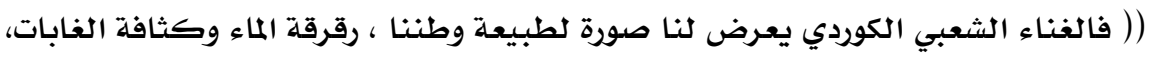

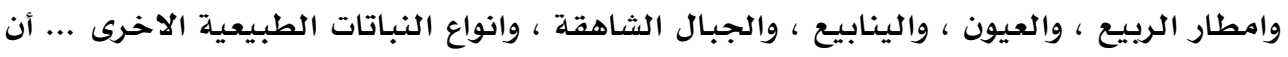

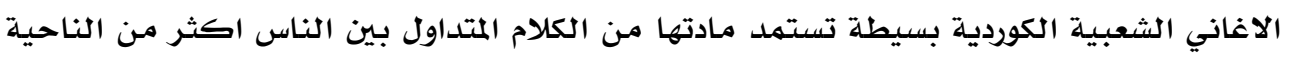

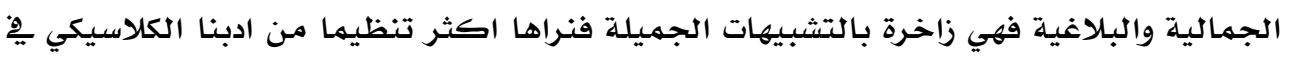

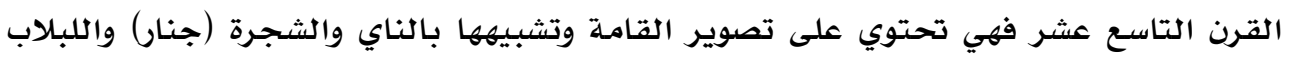

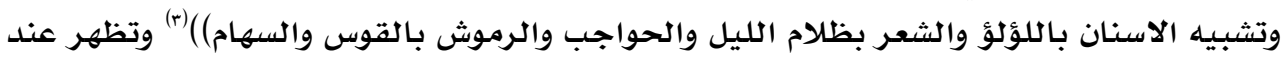

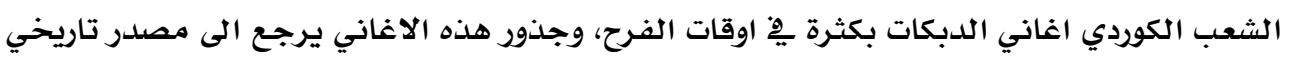

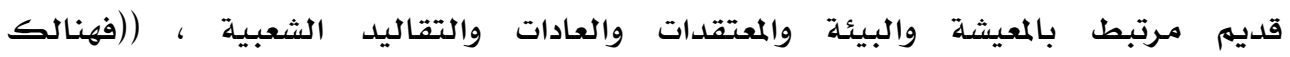

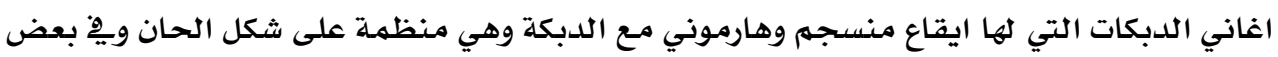

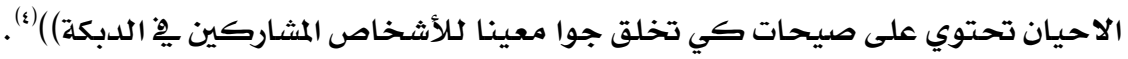

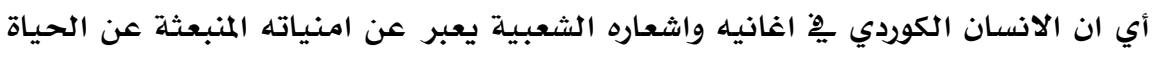

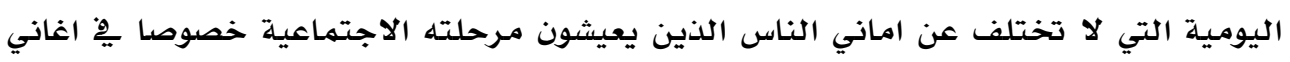

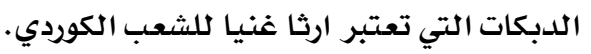

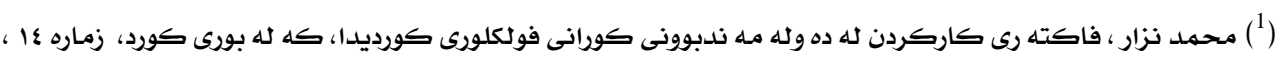

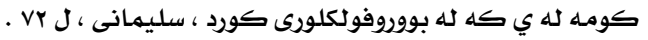

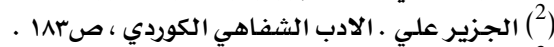

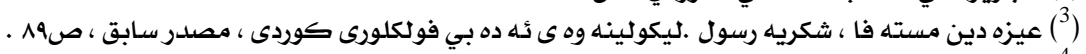

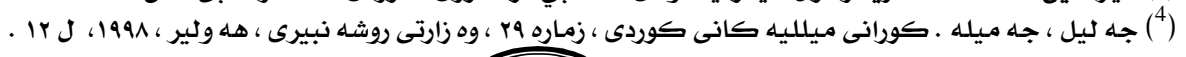


فالغناء والشعر الشعبي الكوردي عبارة عن (( خزين للأثار ومـركز لقاء العشاق وهو يحي

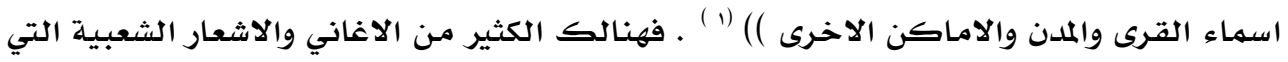
تذكر انواع الازياء الشعبية الكوردية.

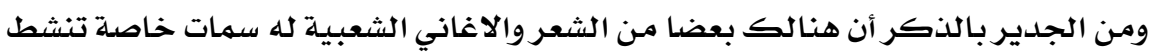

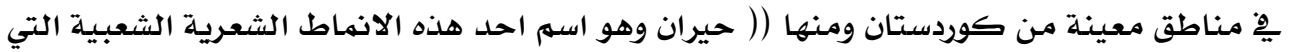

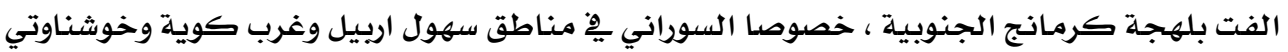

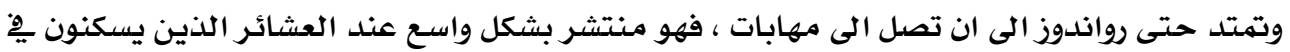

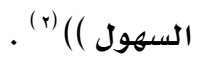

\section{ج- الموسيقى والآلات الموسيقية الشعبية الكوردية :}

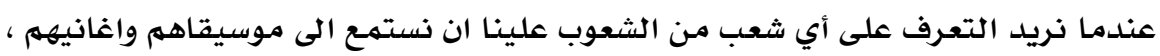

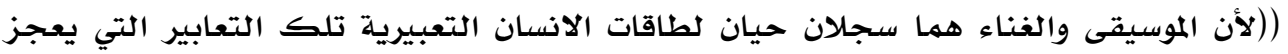

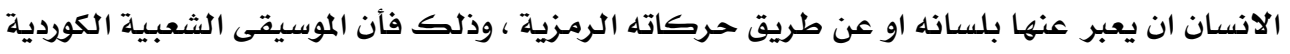

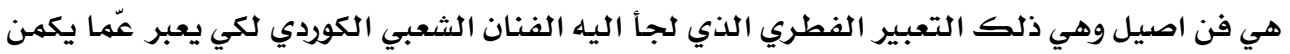

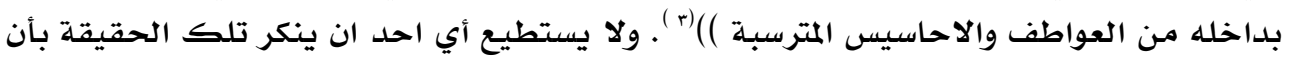
الشعب

الكوردي منذ الازمنـة القديمة كان يهلك العديد من الادوات الموسيقية الاصيلة من (( ده هول

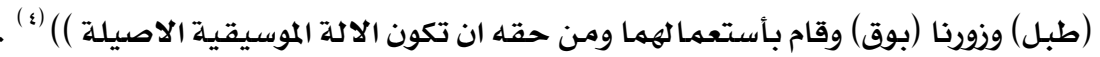

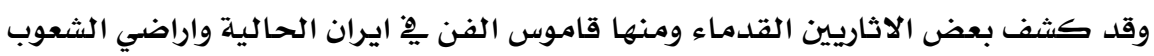

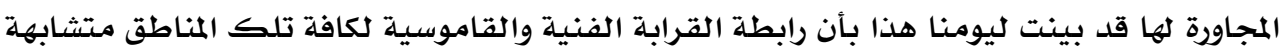

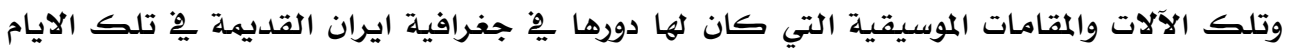

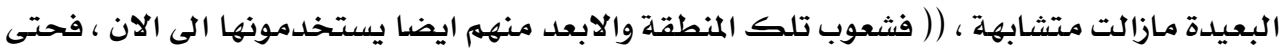

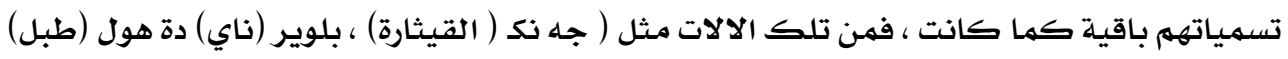

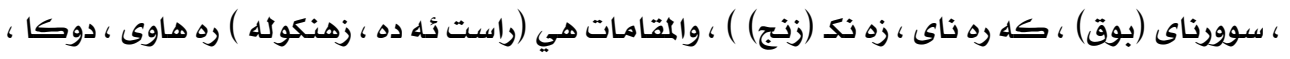

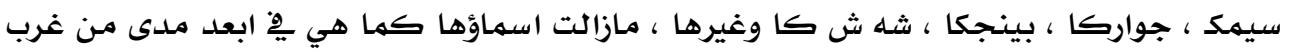

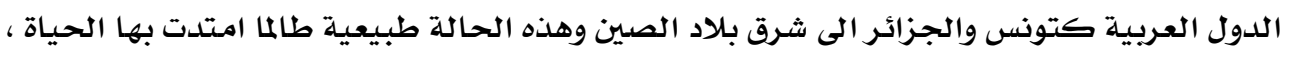

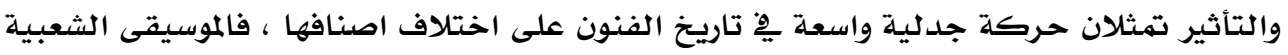

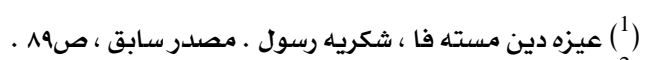

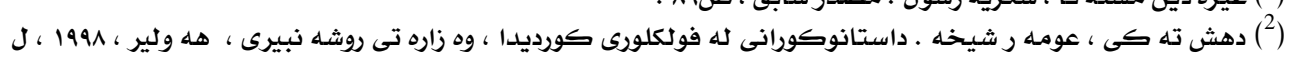
. 110 J-11

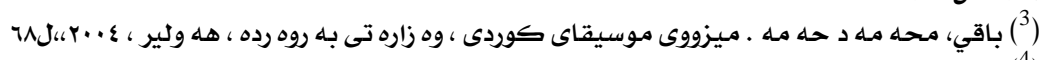


ب r.r. مجلة بحوث التربية النوعية - علد

الكوردية تعبير عن الاحاسيس المترسبة والمستنبطة من بيئتها الحياتية ومن الحضارات القديهـة

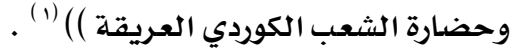

فالحضارة والمراحل الموسيقية الايرانية القديمة (اصبحت قاموسا مشتركا بين شعوب

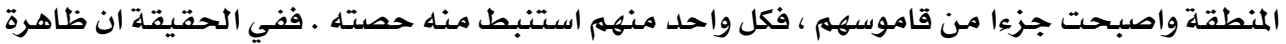

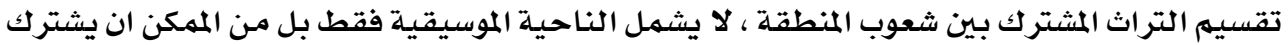

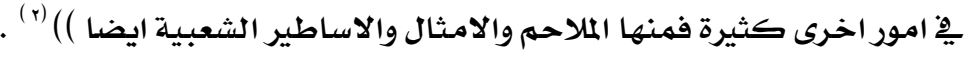

ويرى الباحث الابداعات الشعبية اغلبيتها كانت من خاصية المبدع الفرد فهـع مـرور الزمن فئن

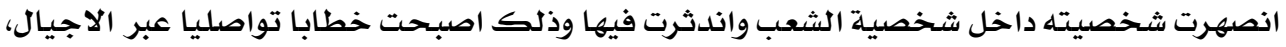

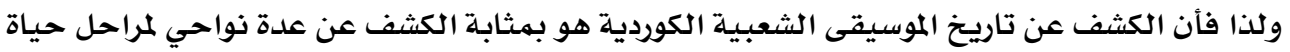
الشعب الكوردي واثبات تراثه كي يدوم خطابه الفكري ويبني تاريخه الجدير عليه ليبقى صامديدا

بوجه اعدائه .

(( وترتبط هذه الحقائق بالظروف ومستوى القدم وضغوط الامبر اطوريات الكبيرة التي

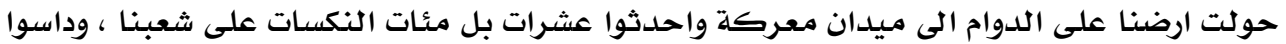

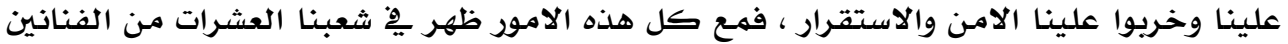

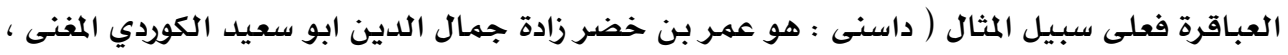

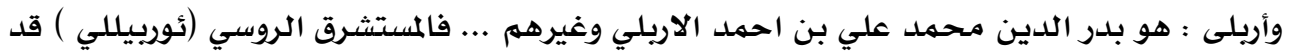

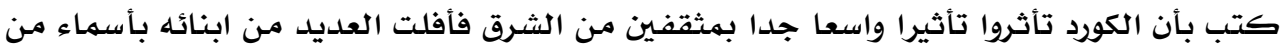

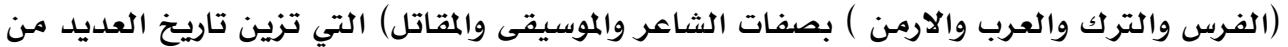

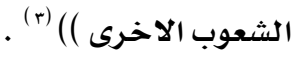

فالفرد الكوردي يتفاعل مـع مقتضيات بيئته فو يحمل طابعها ويلتقط موضوعاته منها،

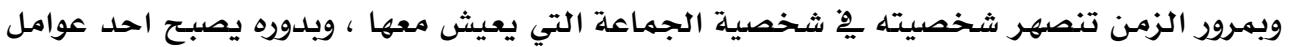

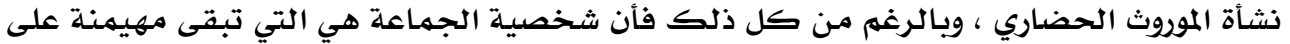

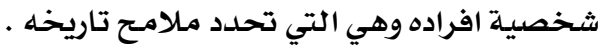

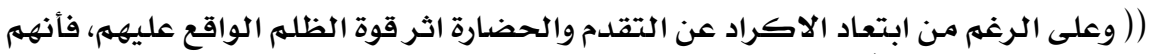

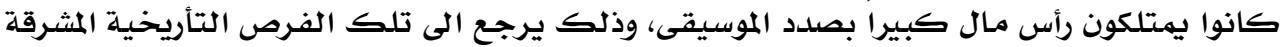

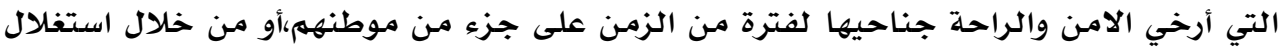

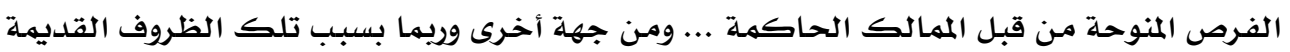

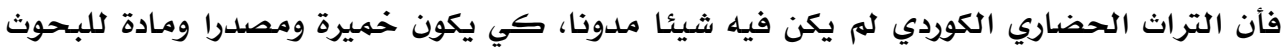

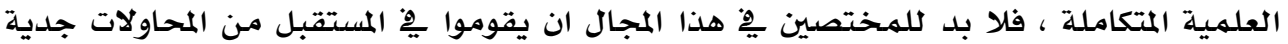

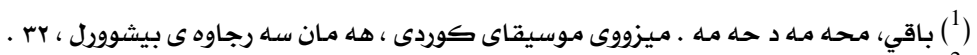

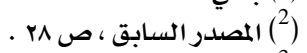

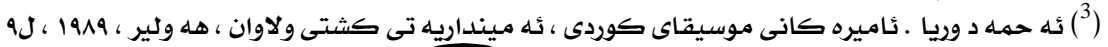




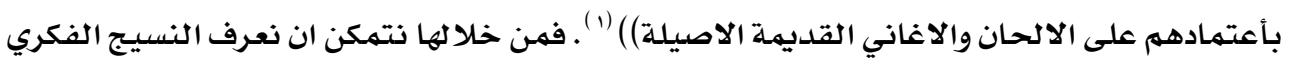

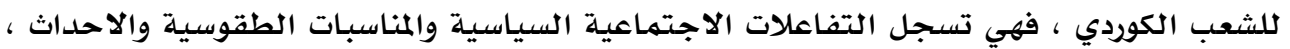

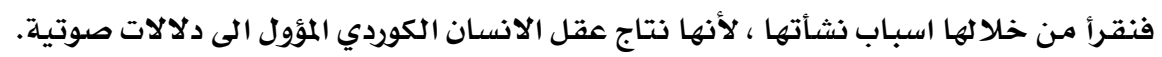

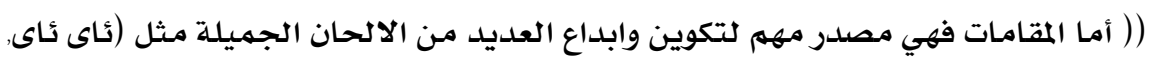

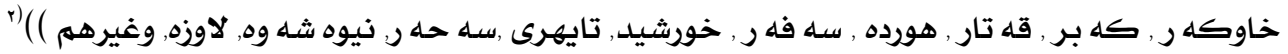
• فلابد من وجود محركات فكرية للفرد الكوردي وعدة مرجعيات الاستنباط وولاة الهامـة

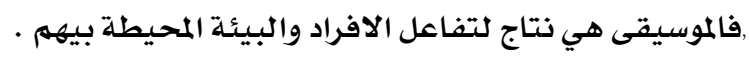

( ( وكانت الالحان العراقية بشكل عام والكوردية بشكل خاص تنتقل وتحفظ عن طريق

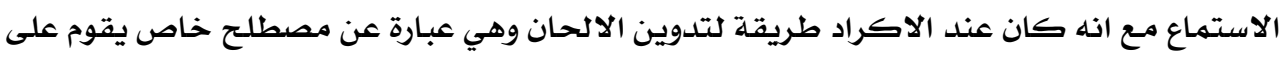

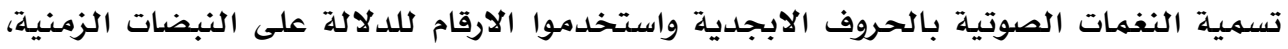

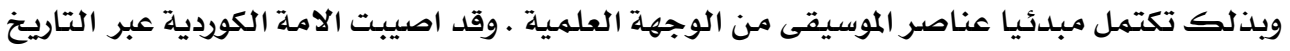

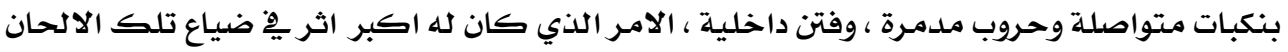

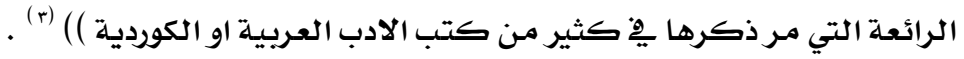
لقد احتلت الموسيقى الشعبية الكوردية مكانه تأريخية مهمـة , وهي احدى الركائز الثقافية

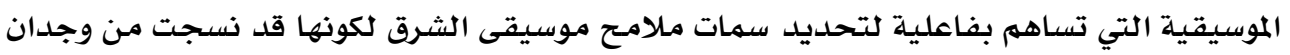

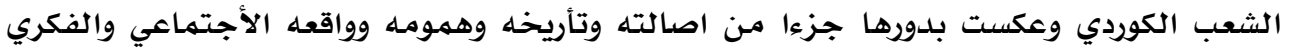

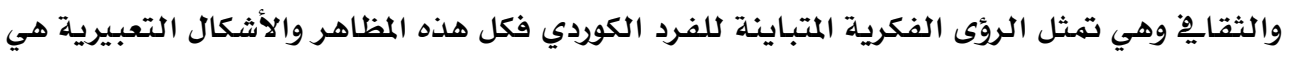

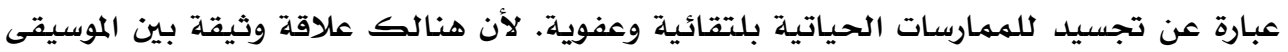

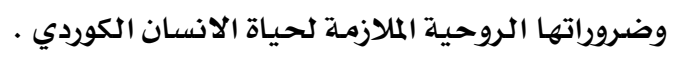

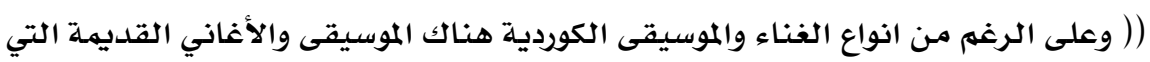

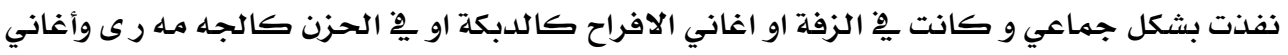

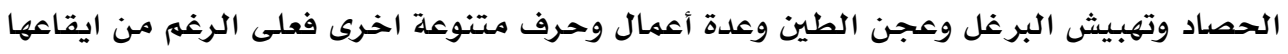

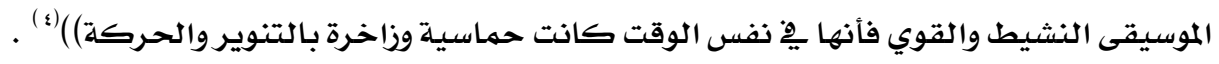

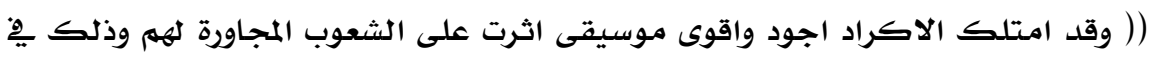

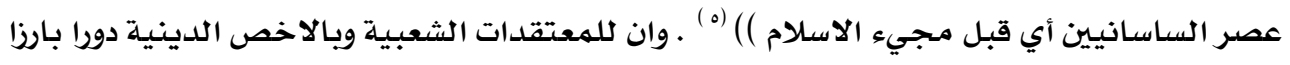

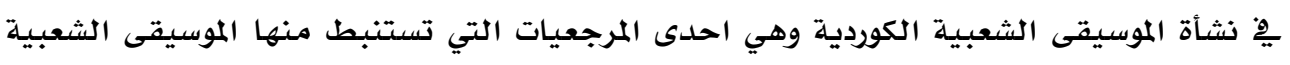
افكارها وموضوعاتها ل الموسيقى الشعاة

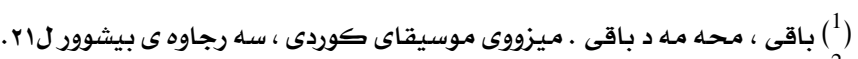

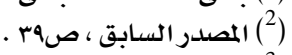

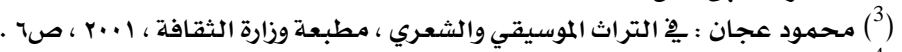

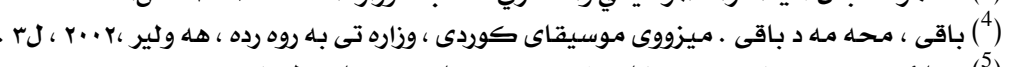

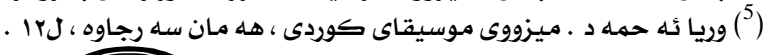




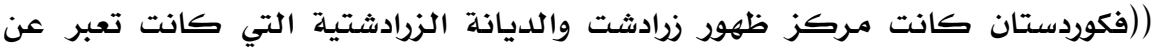

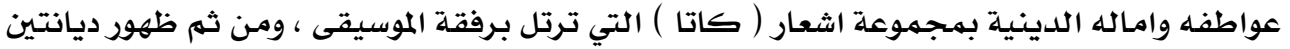

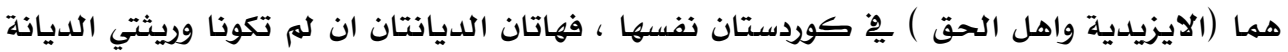

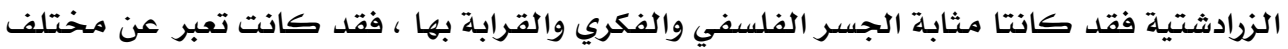

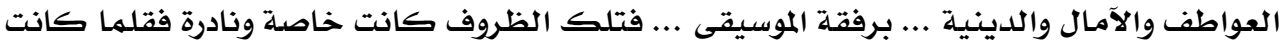

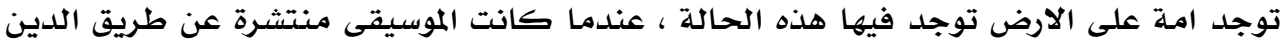

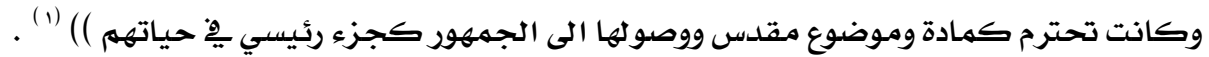
فذلك النوع من الموسيقى الشعبية الكوردية يكثف بدوره عن العقلية المنتشرة وسط

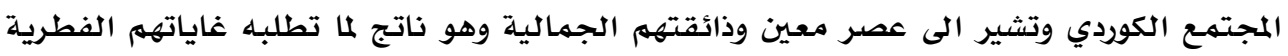

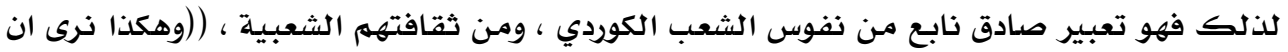

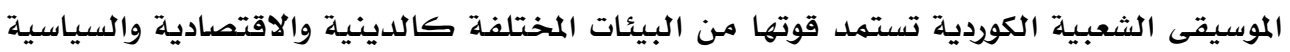

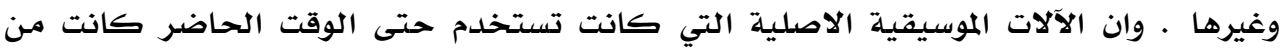

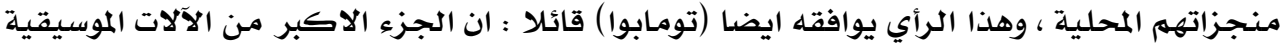

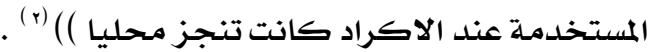

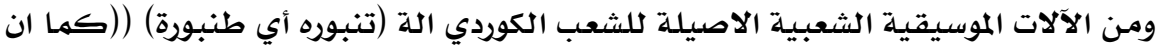

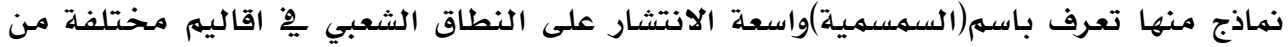

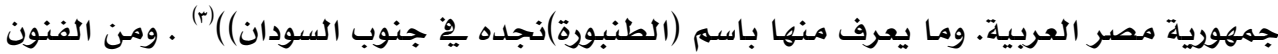

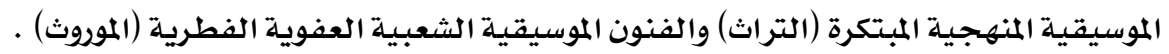
( ( ان الة الطنبورة هي من تلك الآلات التي تستخدم لعدة وظائف بوصفها الة مقدسة

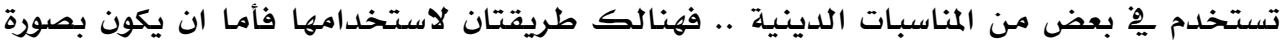

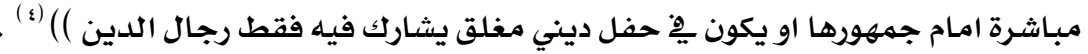

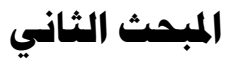

\section{أولا_ النظرية الوظيفية والاجتماعية في الدراسات الفولكلورية}

عندما نتحدث الوظيفة ِيْ علم الفولكلور لدراسـة عناصر التراث الشعبي (عناصرها المادية

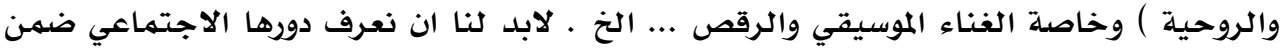

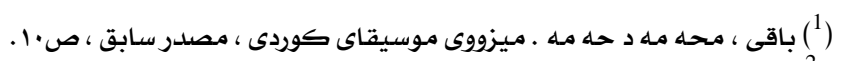

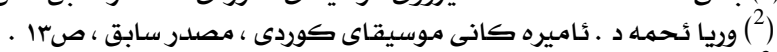

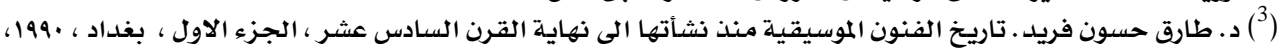

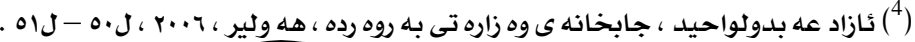


اطارها الوظيفي (( والوظيفة يِّ علم الاجتماع وعلم الانثروبولوجي نزعة او نظرة تنادي بضرورة

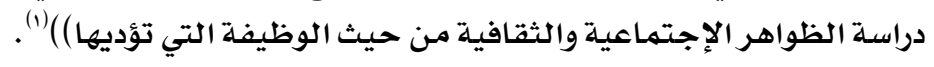

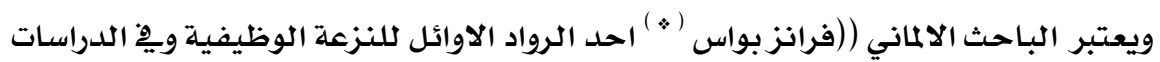

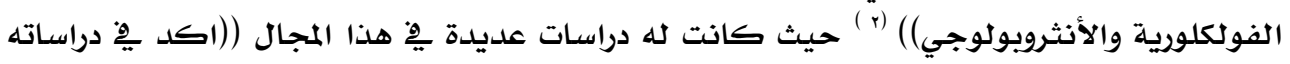

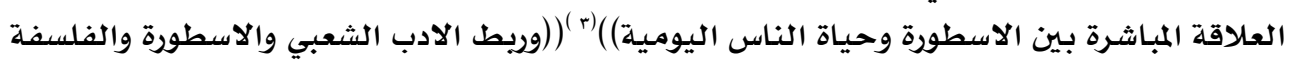

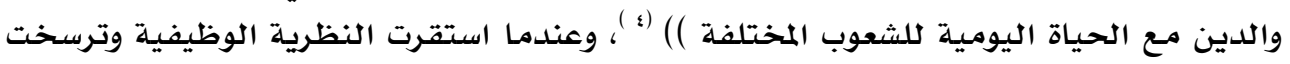

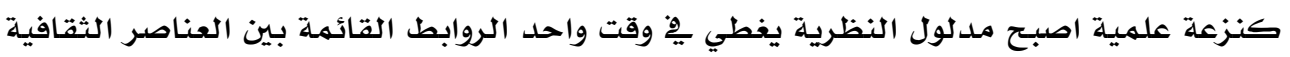

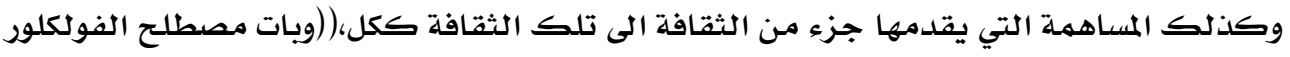

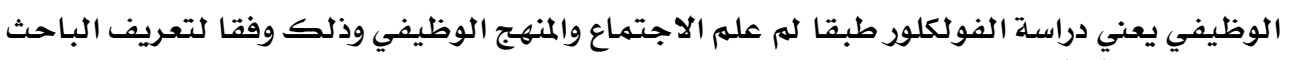

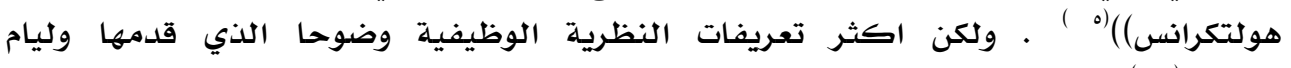

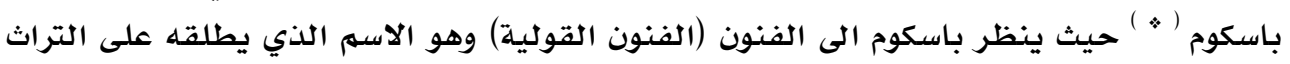

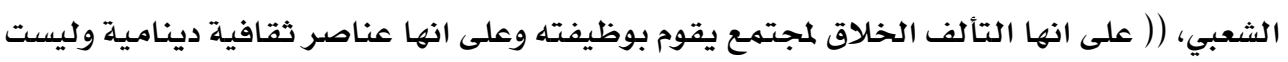

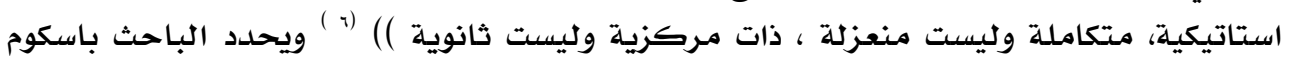

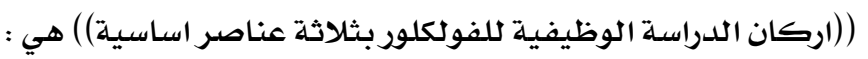

$$
\begin{aligned}
& \text { 1- السياق الاجتماعي للفولكلور ( أي العناصر التراث الشعبي ) ) . }
\end{aligned}
$$

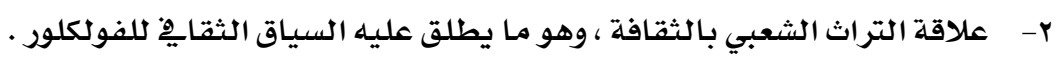

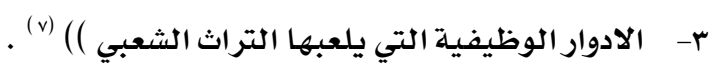

( ) د. طارق حسون فريد ، موجز عله التراث الشعبي (الفولكلور ) ، وزارة التعليم العالي والبحث العلمي ، جامعة بغداد

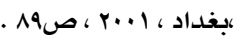

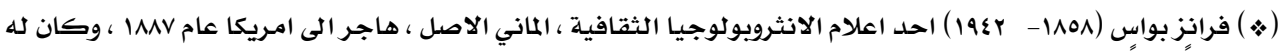

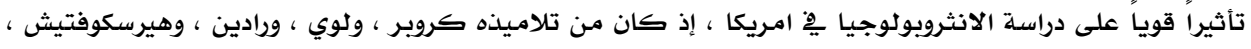

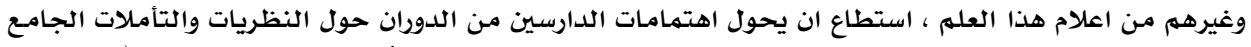

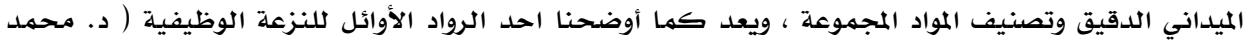

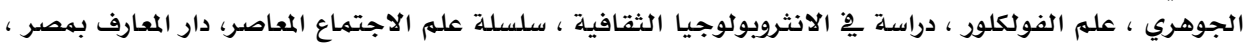

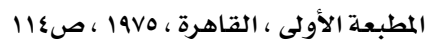

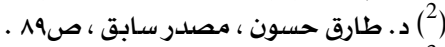

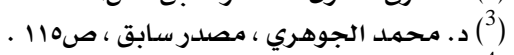

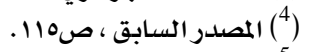

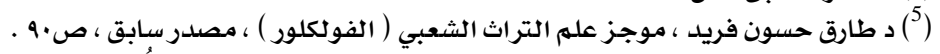

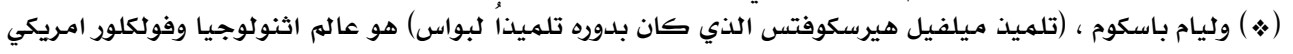

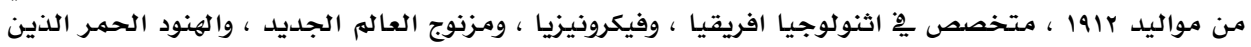

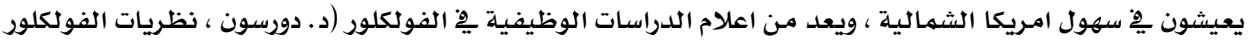

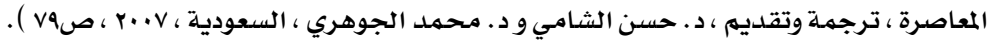

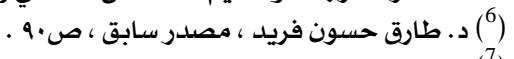

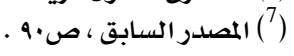




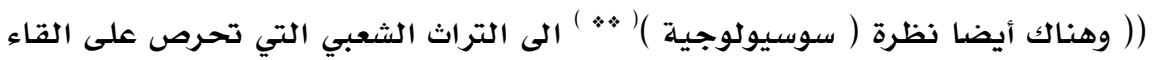

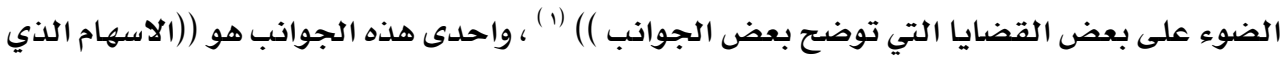

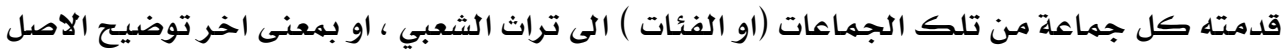

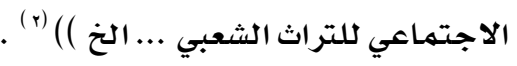

إن الدراسة الفولكلورية يِّ الاتجاه او المعيار الاجتماعي تفرق ((المعيار السوسيولوجي بين

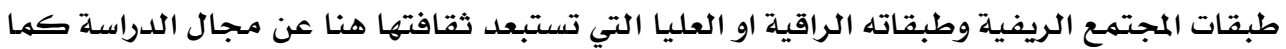

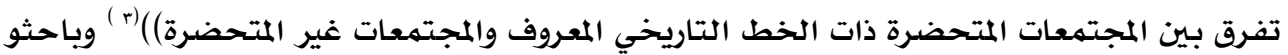

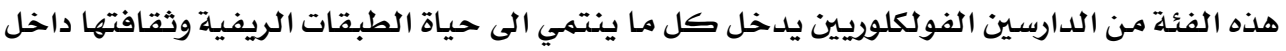

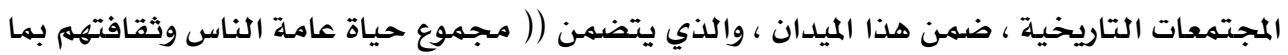

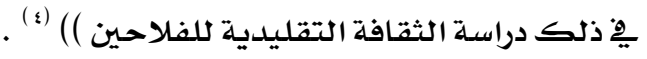
وظهرت الاتجاهات ِِّ دعاة المعيار السوسيولوجي (( وكان الاتجاه الاول عزا اصول التراث

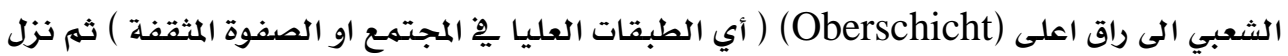

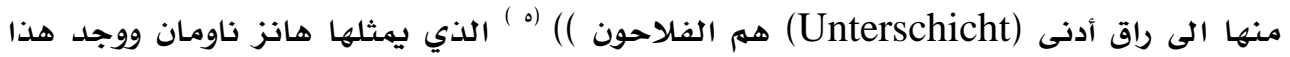

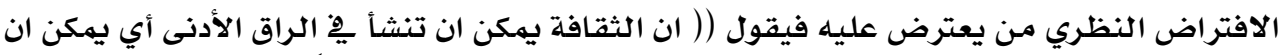

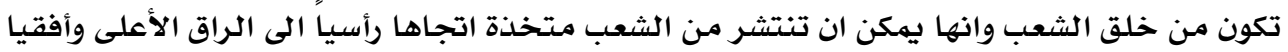

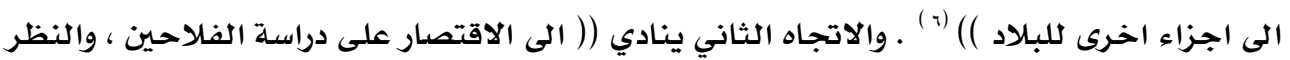

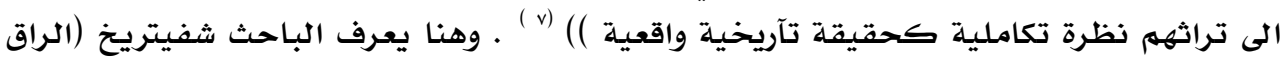

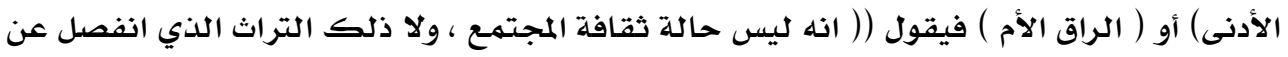

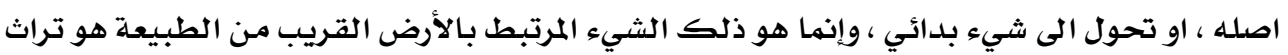

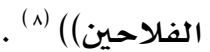

\section{ثانيا الوظيفة الاجتماعية لأغاني العمل}

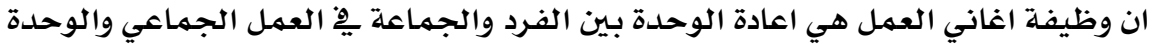

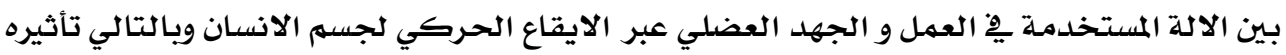

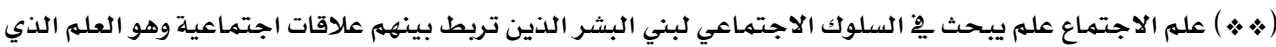

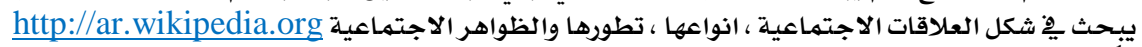
. . .

( )

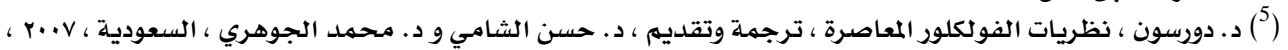
ص ص

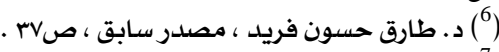

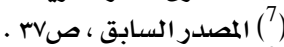

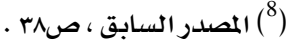


على ايقاع الأغنية وايقاع الأغنية يؤثر او ينظم الايقاع الحركي لجسم الانسان (( يلاحظ التقارب

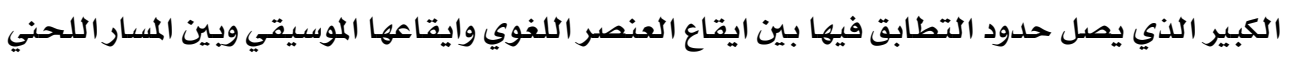

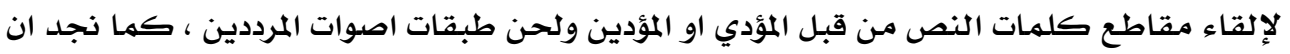

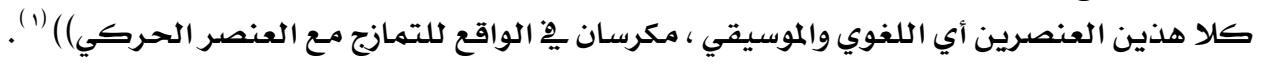

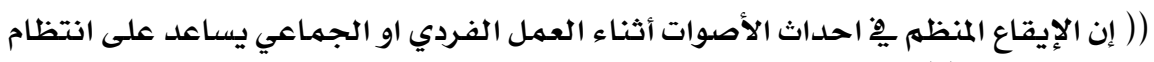

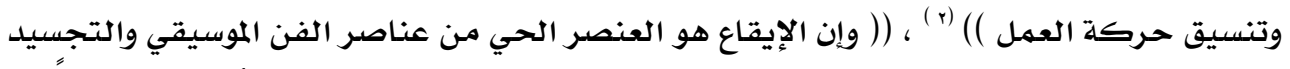

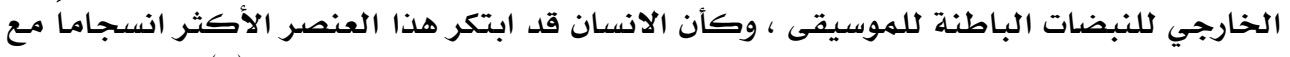

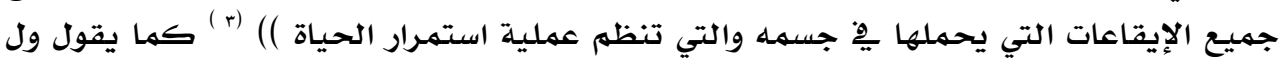

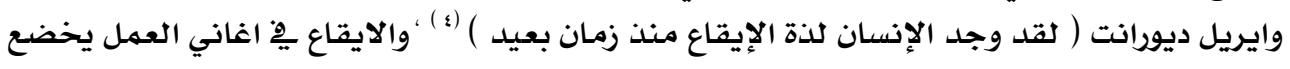

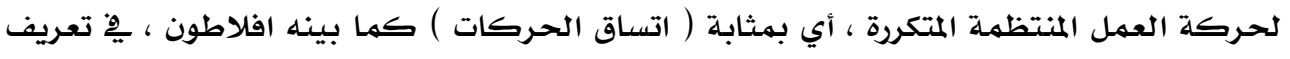

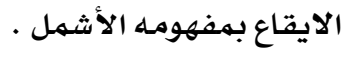

وتهدف اغنية العهل الى (( تنسيق حركة العمل وزيادة مقدرة العمال على بذل الجهال

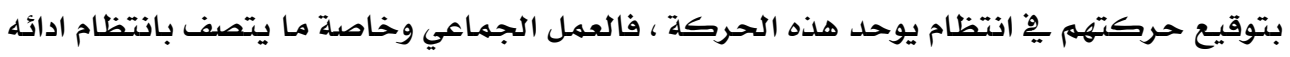

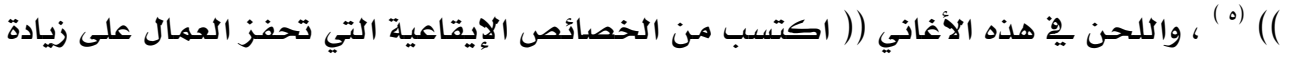

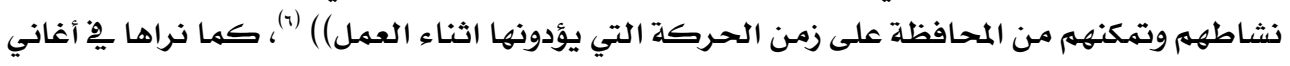

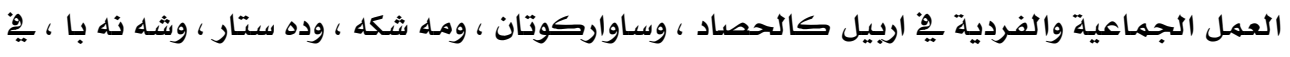

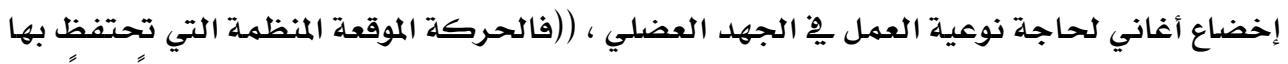

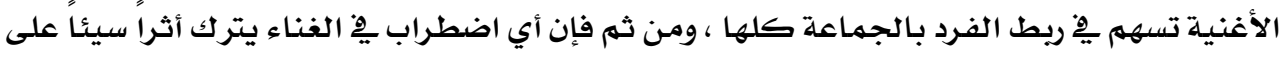

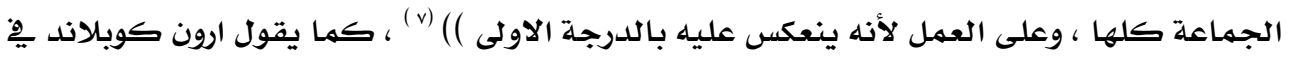

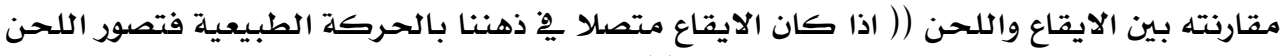

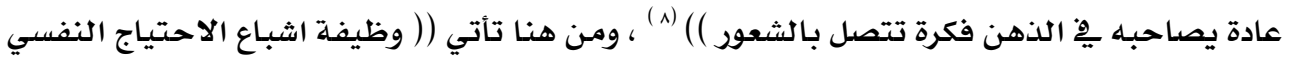

(1) د. طارق حسون فريد ، العلاقة بين الكلمة واللحن بِّْ بعض صيخ التراث والموروث الموسيقي العراقي ، مصدر سابق ،

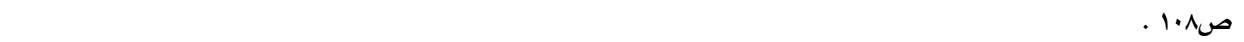

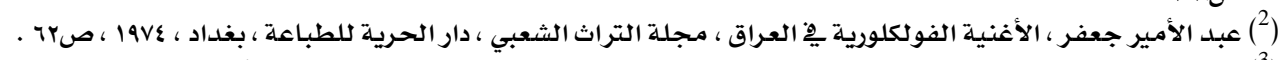

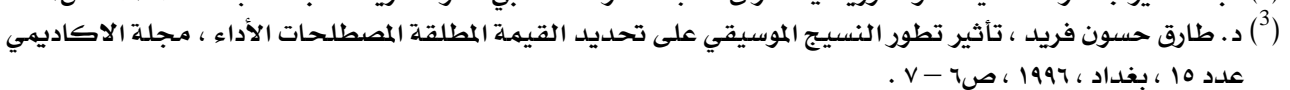

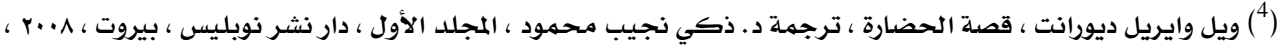
ص 197 (5) د. احمد مرسي ، الاغنية الشعبية ، المكتبة الثقافية ، العدد عهب ، الهيئة المصرية العامة للتأليف والنشر ، القاهرة ،

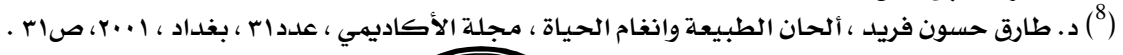




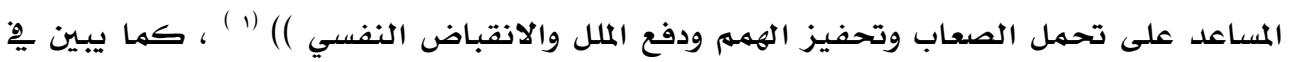

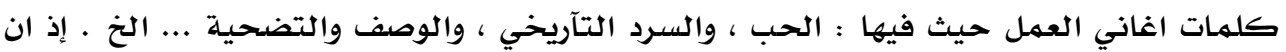

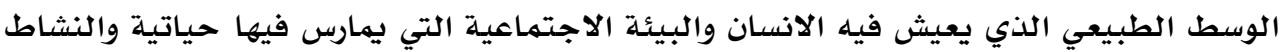

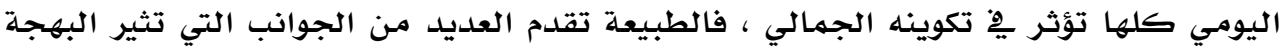
والسرور (r)

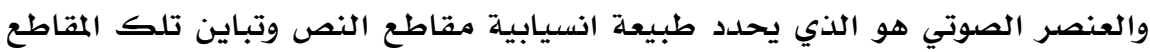

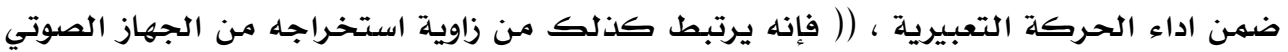

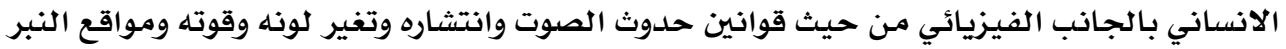

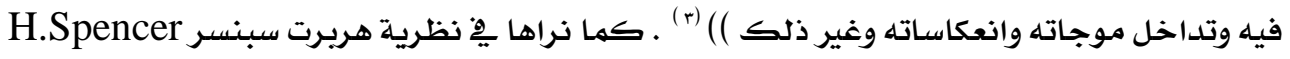

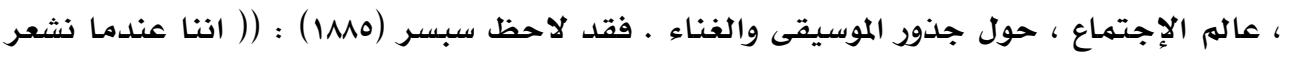

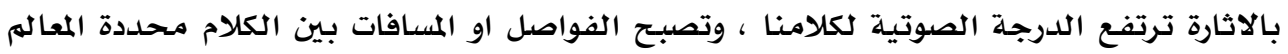

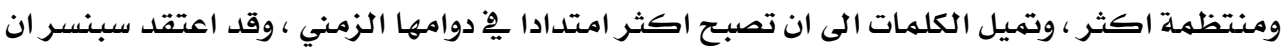

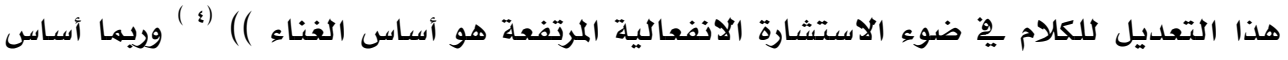

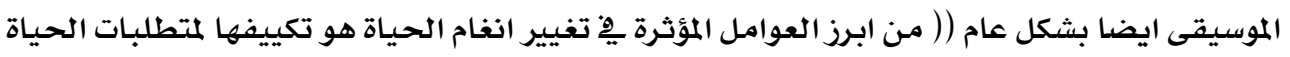

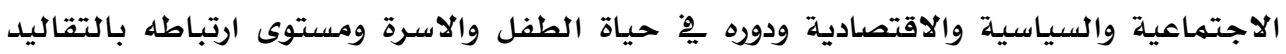

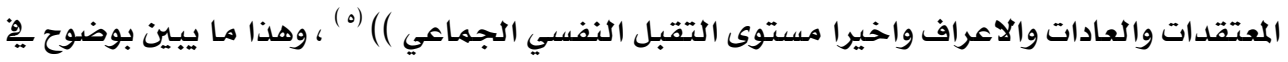

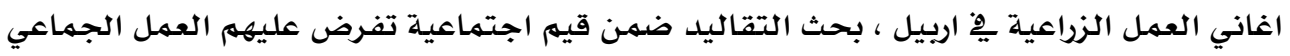

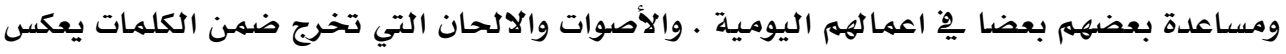

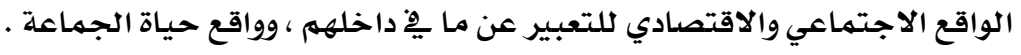

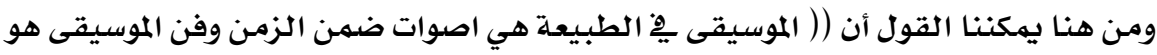

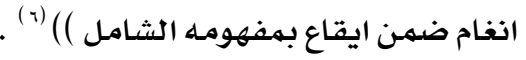

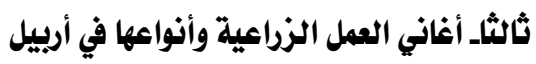

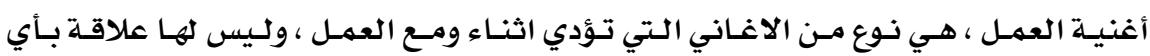

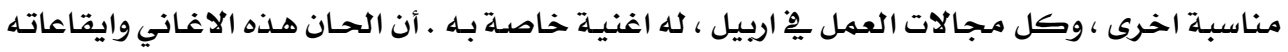

( ) د. طارق حسون فريد ، العلاقة بين الكلمة واللحن ِِّ بعض صيغ التراث موروث الموسيقي العراقي ، مصدر سابق ،

ص.7.

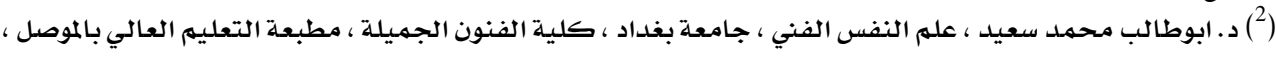

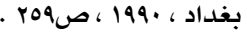
(3) د. طارق حسون فريد ، العلاقة بين الكلمة واللحن يِّ بعض صين التراث موروث الموسيقي العراقي ، مصدر سابق ، ص. 11 .

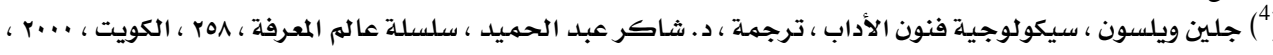

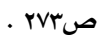

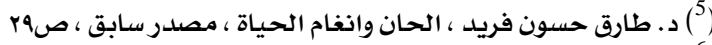

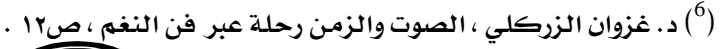


ينسجم مـع حركة الأرجل والأيادي العاملة ، والهدف المنشود من هذه الأغاني وكذلك نوعية العهل

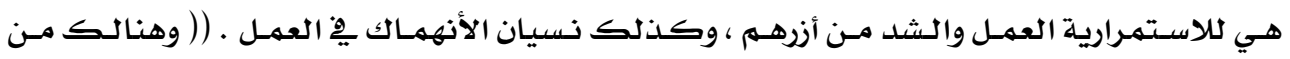

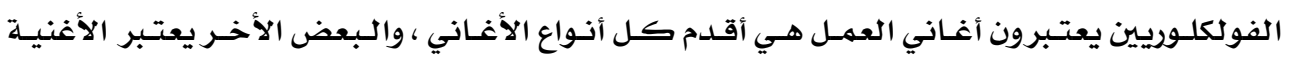

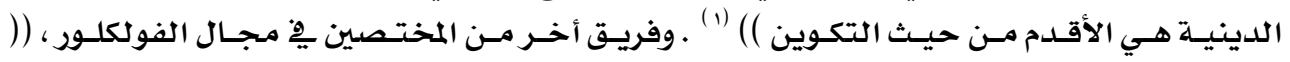

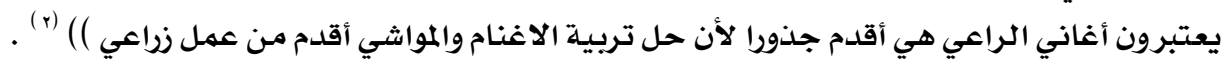

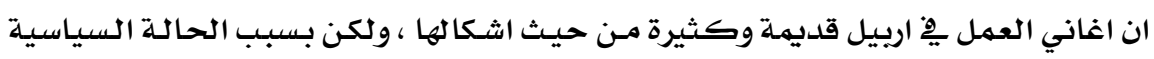

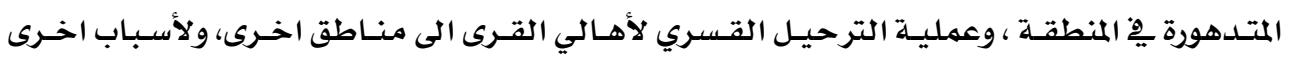

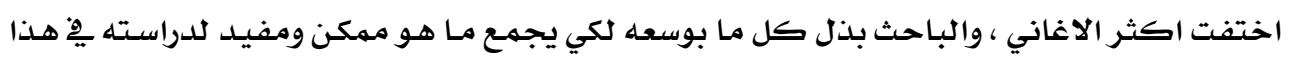

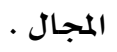

\section{اـ اغنية الحصاد ( دروينه )}

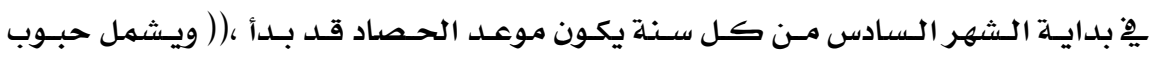

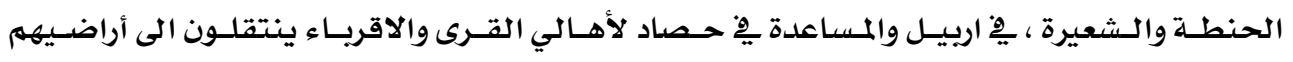

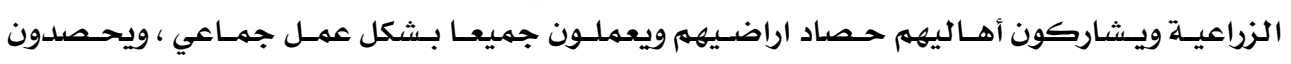

$$
\text { حصص البيوت تلو الأخر . }
$$

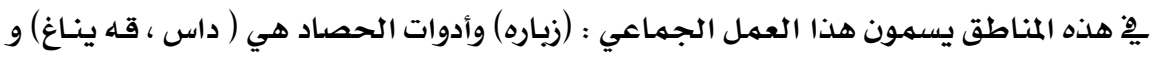

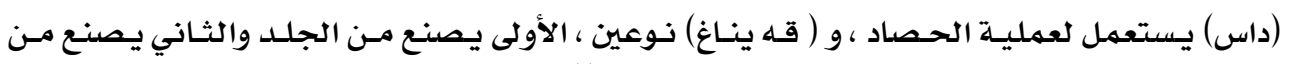

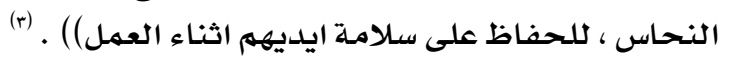

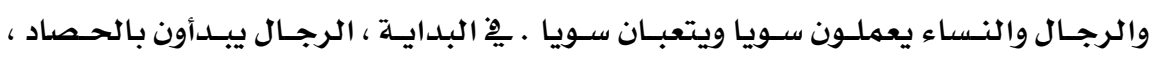

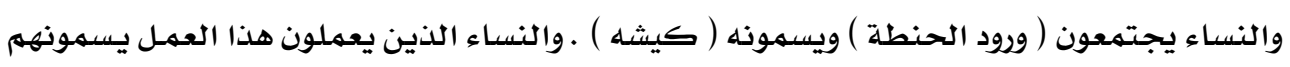

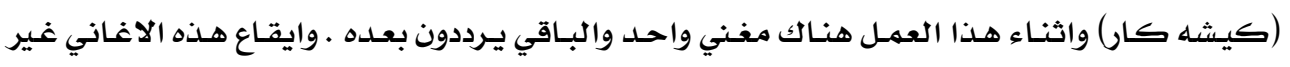

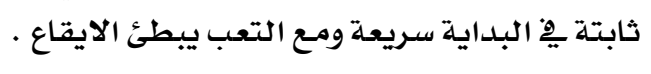

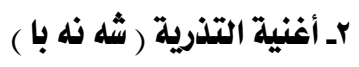

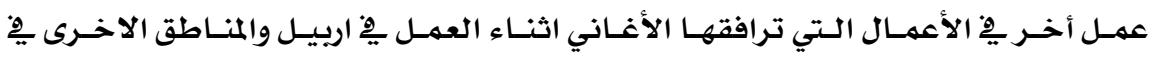

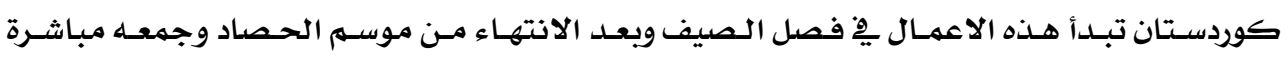

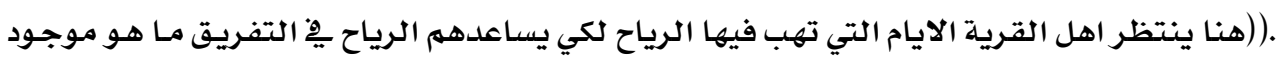

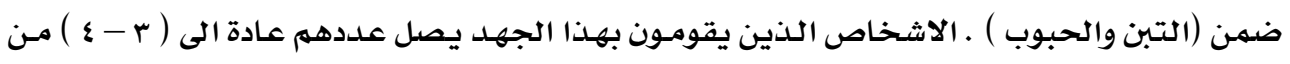

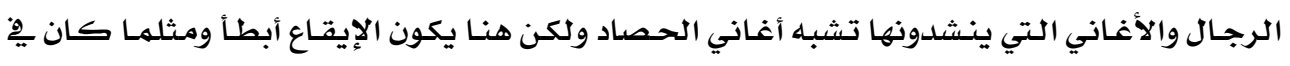

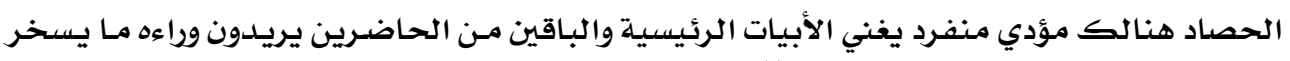

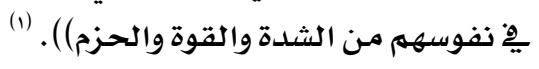

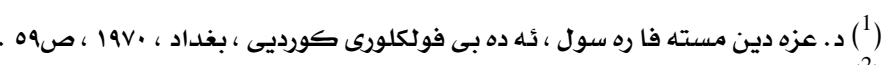

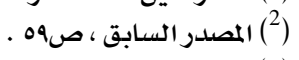

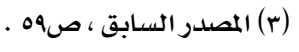


rـ أغنية طحز الحنطة ( ساوار كوتان ) وطحز البرغل (دقه)

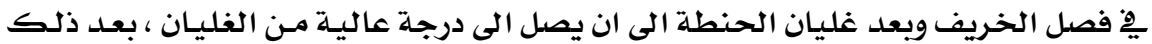

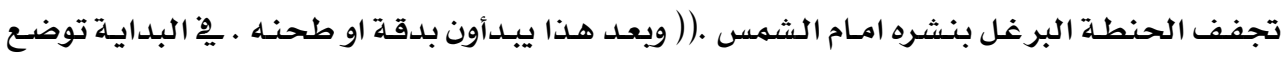

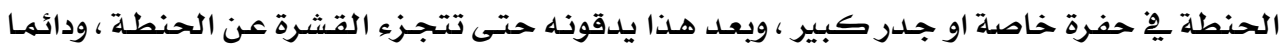

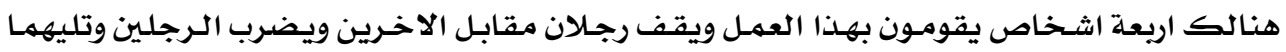

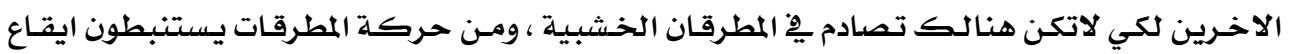

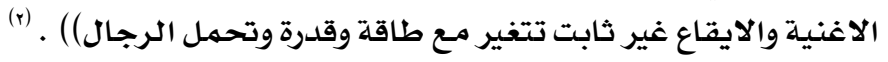
كـ اغنية مجرشة او مطحنة يلدوية ( ده ستار )

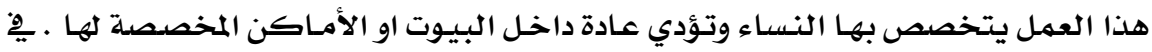
بعض الأحيان هنالك امرأة واحدة تقوم بهذا العمل ولكن عادة تشارك اكثر من امـرأة (ريما امـرأتان )

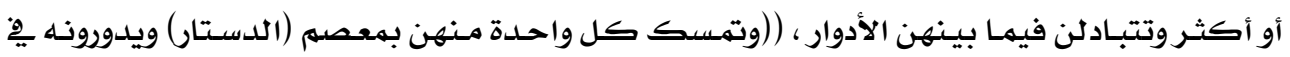

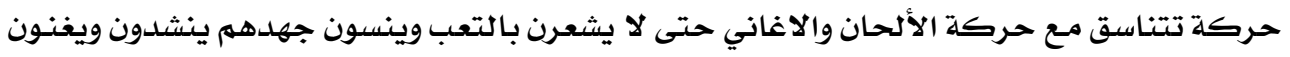

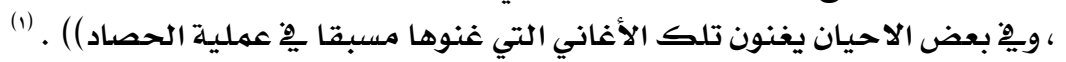
0ـ أغنية مهخضة (مه شكه )

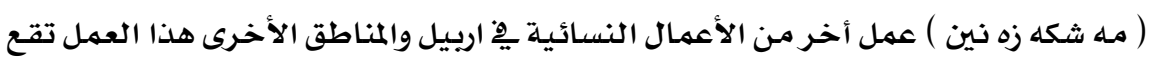

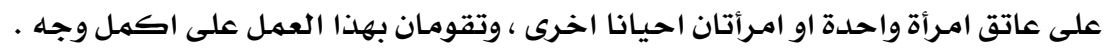

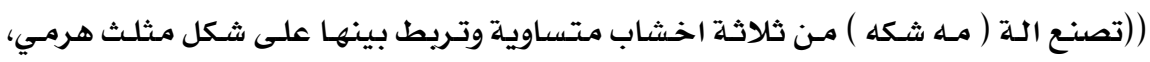

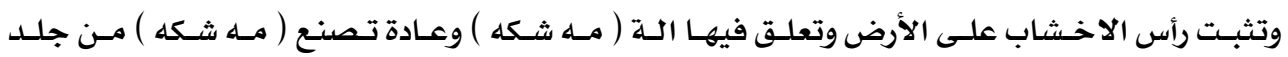

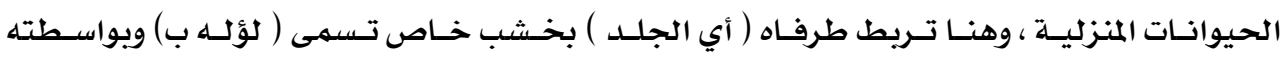
تتمسك (مه شكه) وتبدو جاهزة للعمل .

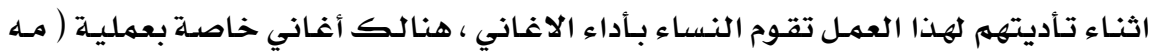

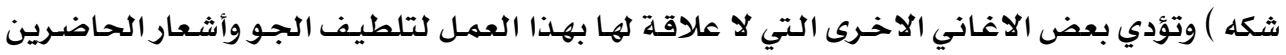

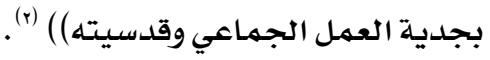


اسم المؤدي : خضر قادر رسول

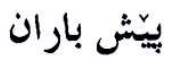

اللحن :
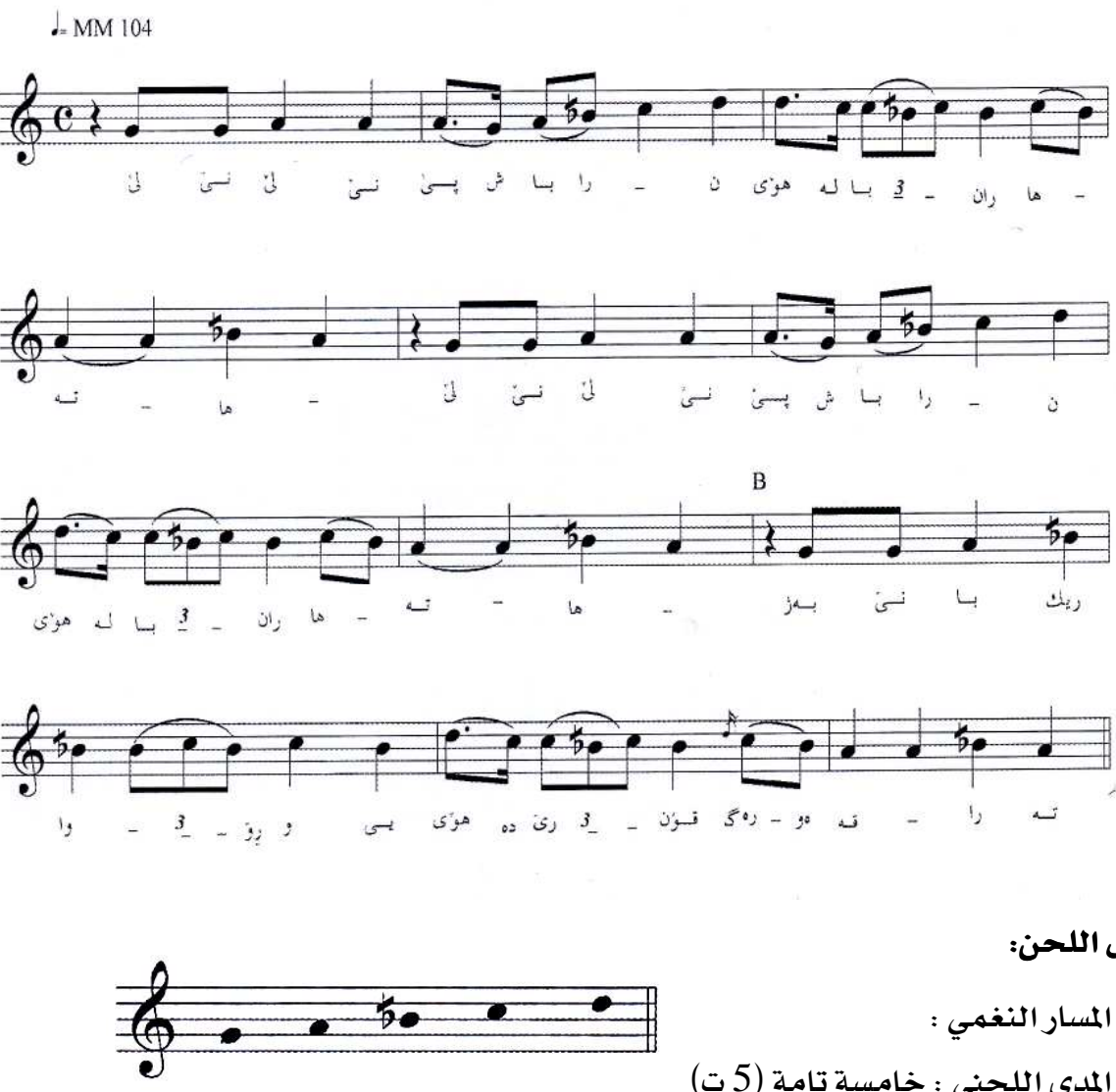

تحليل اللحن:

ا ـ المسار النغهي :

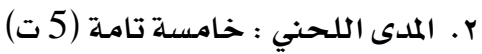

r. ب. نغمـة الإبتداء

a : نغمة الإنتهاء

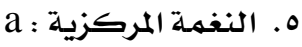

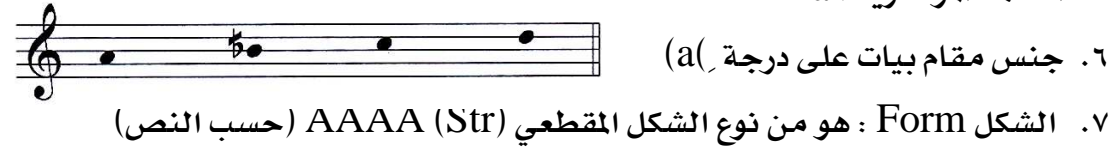


^. احصائية الأبعاد المستخدمة :

\begin{tabular}{|c|c|c|c|c|}
\hline ثالثة الرست & rك & ثانية البيات & الأولى (أونيسوز) & حجوم الابعاد \\
\hline 1 & $\checkmark$ & 17 & \multirow[t]{2}{*}{ iv } & الابعاد الصاعدة \\
\hline - & 7 & iv & & الابعاد الهابطة \\
\hline
\end{tabular}

9. الشكل الإيقاعي اللحني :

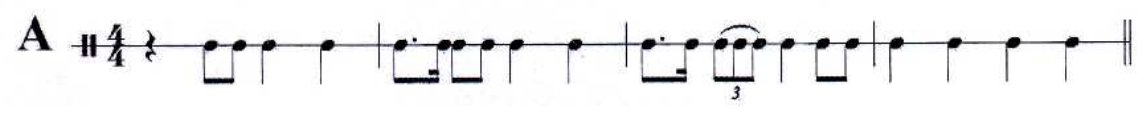

1. ا. الضرب الإيقاعي : مقسوم

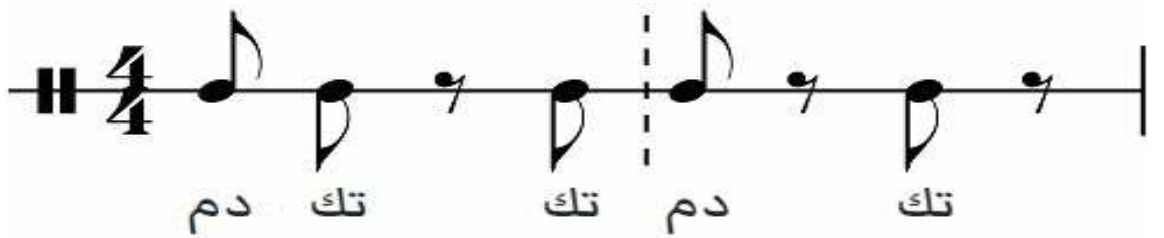

نتائج البمث وتفسيرها

من خلال التحليل الموسيقي للعينة اتضح الاتي:

1. النطاق الصوتي لا يتعدى مسافة الخامسة (هت)

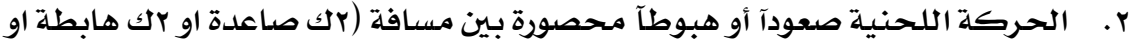

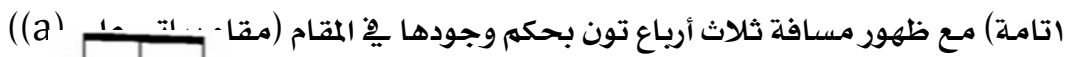

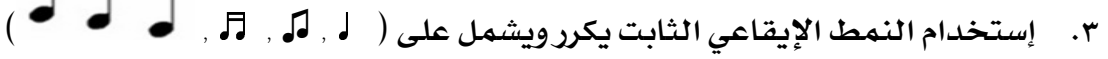

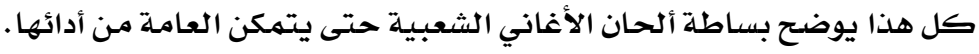

\section{همادر اللغة العربية}

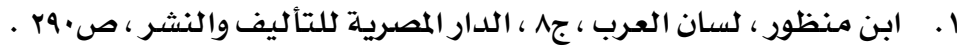

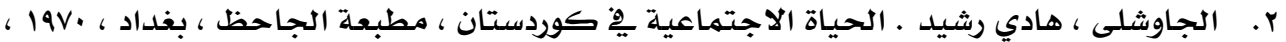
صTr.

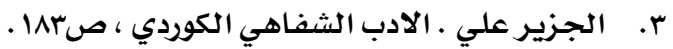

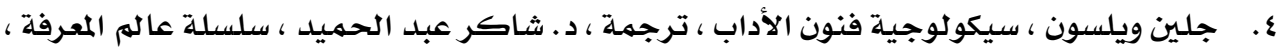

$$
\text { ا }
$$

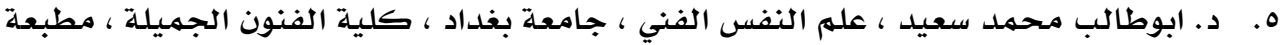

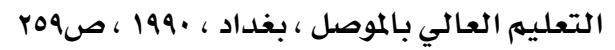

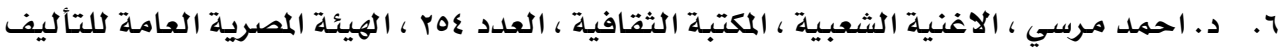

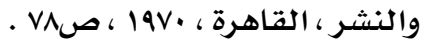


V. د. حسـام يعقوب اسحق، مجلة الاكاديهي(الموسيقيون- موسيقيتهم- وسهعهم الموسيقي)

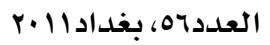

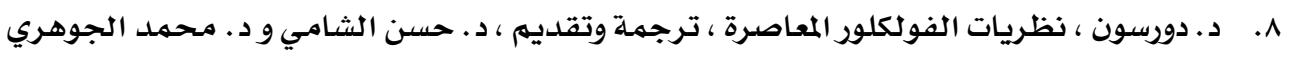

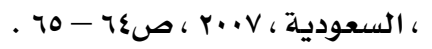

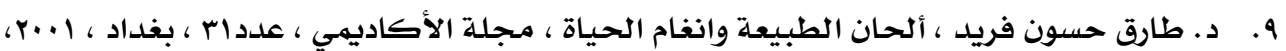

صטا" •l. د. طارق حسون فريد ، تأثير تطور النسيج الموسيقي على تحديد القيمة المطلقة المصطلحات

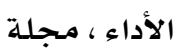
11. rا. . د. طارق حسون فريد ،تاريخ الفنون الموسيقية منذ نشاتها الى نهاية القرن السـادس عشر,الجزء

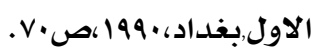

سا. د.. طارق حسون فريد ، موجز علم التراث الشعبي (الفولكلور ) ، وزارة التعليهم العالي والبحث

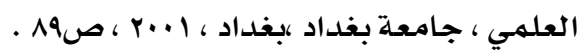

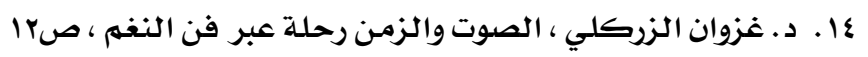
10 . د. مححمد الجوهري ، علم الفولكلور ، دراسـة يِ الانثروبولوجيا الثقافية ، سلسلة علم الاجتماع

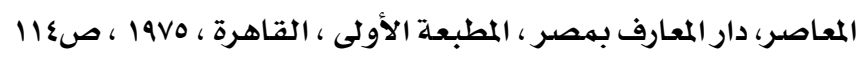

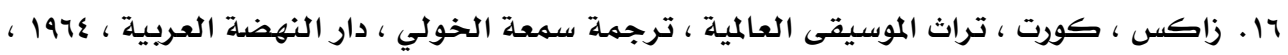
$\varepsilon \varepsilon$

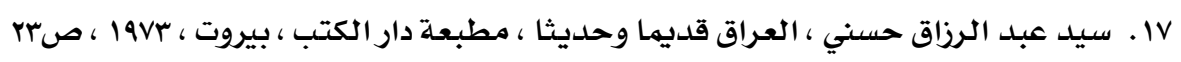

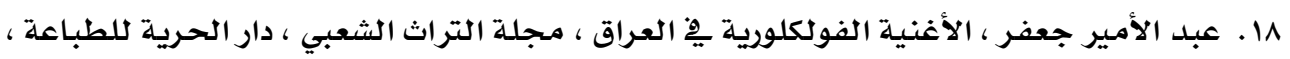

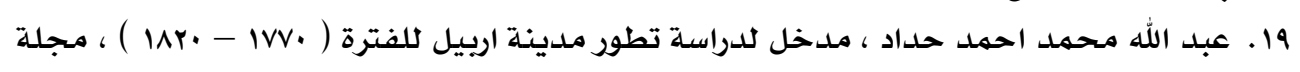

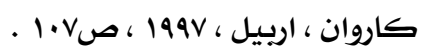

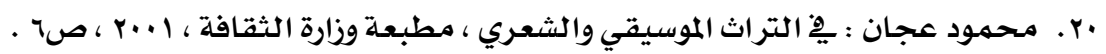

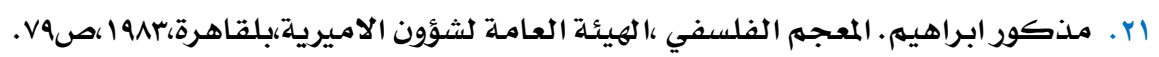
r. . هادي رثيد الجاوشلي ، تراث اربيل التاريخي مطبوعات الامانة العامـة الادارة الثقافية والشبـاب، 110ص، 1910 بr. ويل وايريل ديورانت ، قصدة الحضارة ، ترجمـة د. ذكي نجيب محمود ، المجلد الأول ، دار نشر

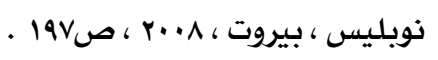

همسادر اللغة الكورودبية

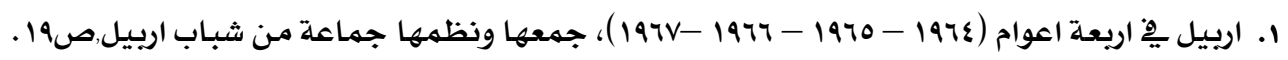

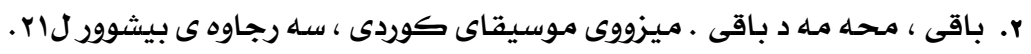

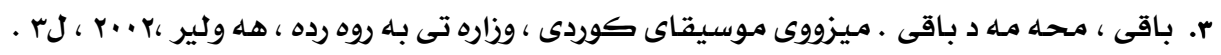




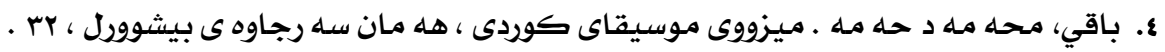

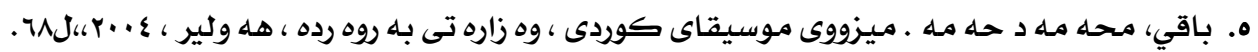

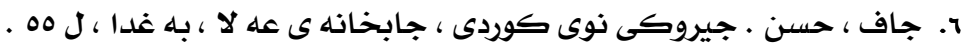

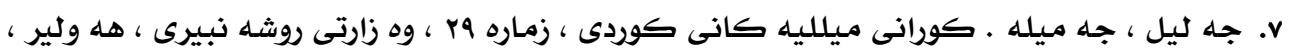

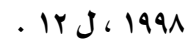

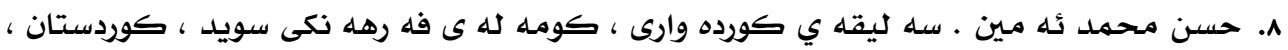
$.1 .0 J$ ، 1998

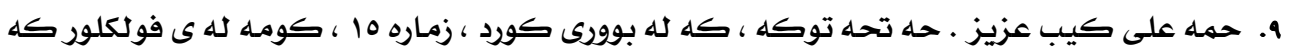

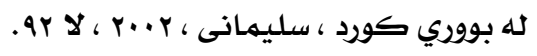

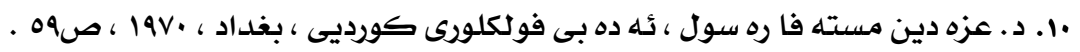

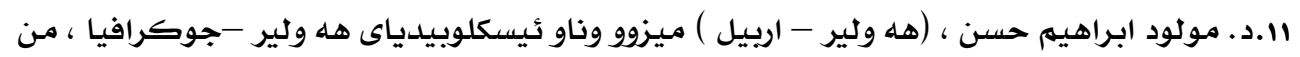

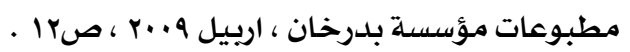

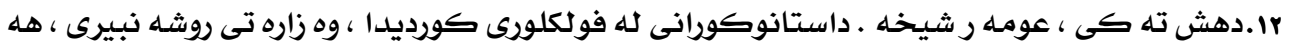

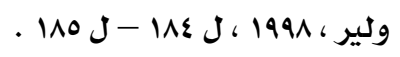

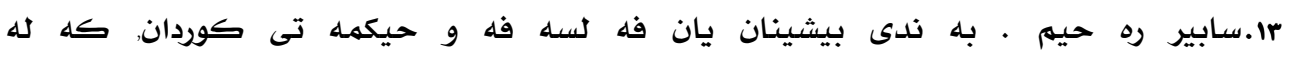

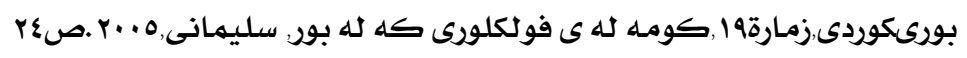

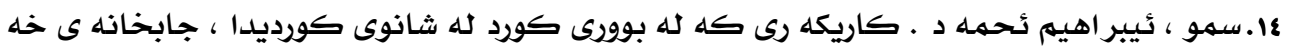

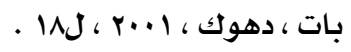

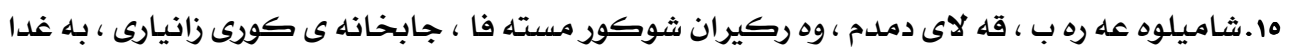

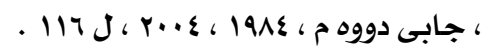

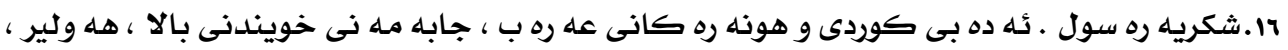
. 1919 vا.عزيز ابراهيهم عمـر. هـ ندى داب ونه ريتي باوي كوردة واري ، زنجيرة ى 190 ، ، دة ز طاى رؤشنبيرى و

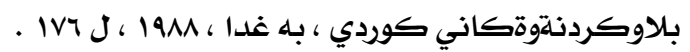

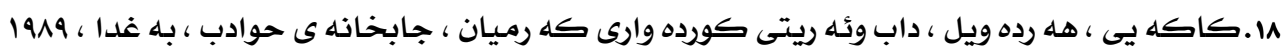
.

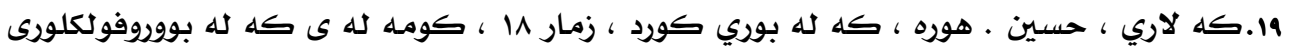

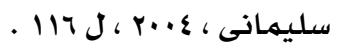

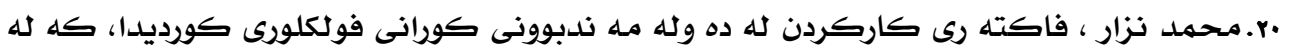

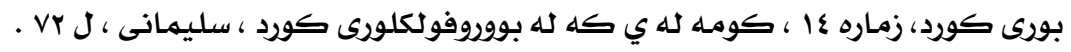

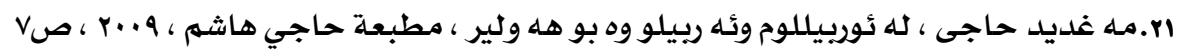

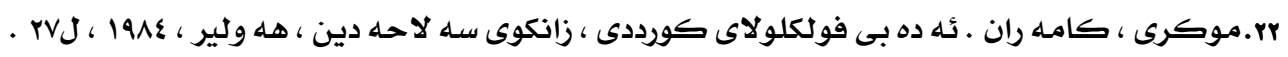


rr.مينورسكى · كورد ، وه ركيرانمارفخه زنه دار ، حه مـه سـه عيد كاه ريهم ، جابخانه ى زانكو ىسسه

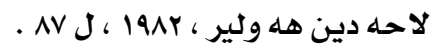

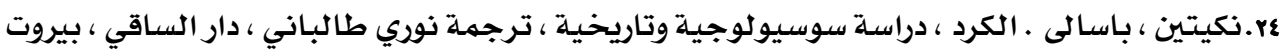
. Irrma r...

0..نه بـه ز ته وفيق . هـ نديك له يارى ره سـه نه كانى كورده وارى جابخانه ى الحوادث ، بـه غدا ، . V ، 1919

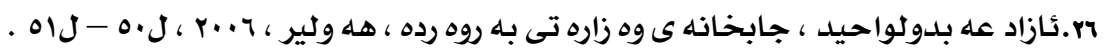

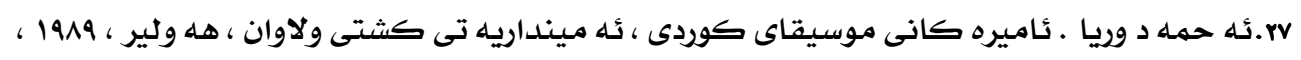
.

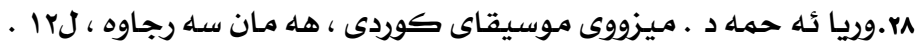

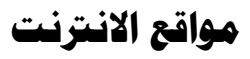

$\underline{\text { http//www.almaany.com }}$

$$
\text { ا. ان موقع المعاني }
$$

\section{htt//www.almaany.com}

$\underline{\text { http://www.almaany.com }}$

$$
\text { r. المعجم الوسيط ،موقع المعاني يِّ الانترنيت }
$$

r. موقع عالم الفنون الشعبية يِّ الانترنيت

http://www.kenanaonline.com/users/ahmedsalahkhab/posts/97490

http:// www.arab-wikipedia.org

$$
\text { ع. موقع ويكيبيديا الموسوعة الحرة يِّ الانترنيت }
$$

http://www.arab-ency.com

$$
\text { ه. موقـ الموسوعة العربية يِ الانترنيت }
$$

T. الموقع الرسمي لمحافظة اربيل يِّالانترنيت

http:/www.hawlergov.org/ara/subject.aspx?ID=50 


\section{The musical characteristics of agricultural songs working in Erbil}

\section{Abstract}

consists of two chapters

The first chapter, the researcher addressed the research problem, as the research and studies that dealt with the subject of the Kurdish popular song, especially work songs, were not touched upon by the researchers in terms of music, and that losing and forgetting the largest part of these songs in form and content, was the reason for defining the research problem, as he explained the importance of the research As one of the music studies in Iraqi Kurdistan that sheds light on the songs of work in Erbil, the aim of the research is to reveal the characteristics of these songs in terms of melodic and rhythmic aspects and their social function in Erbil. As for the limits of the research, it was limited to the songs of the work from 1960-1970 He urged the terms contained in the search.

The second chapter consists of two topics: The first topic consists of a historical summary about the history of the city of Arbil (hee lehre), Kurdish customs, traditions, beliefs, Kurdish folk literature, Kurdish poetry, Kurdish singing, music, and Kurdish popular musical instruments, while the second topic consists of functional and social theory in folklore studies and The social function of agricultural work songs and agricultural work songs and their types in Erbil

Then a sample of the agricultural work song followed by a sample in English . 